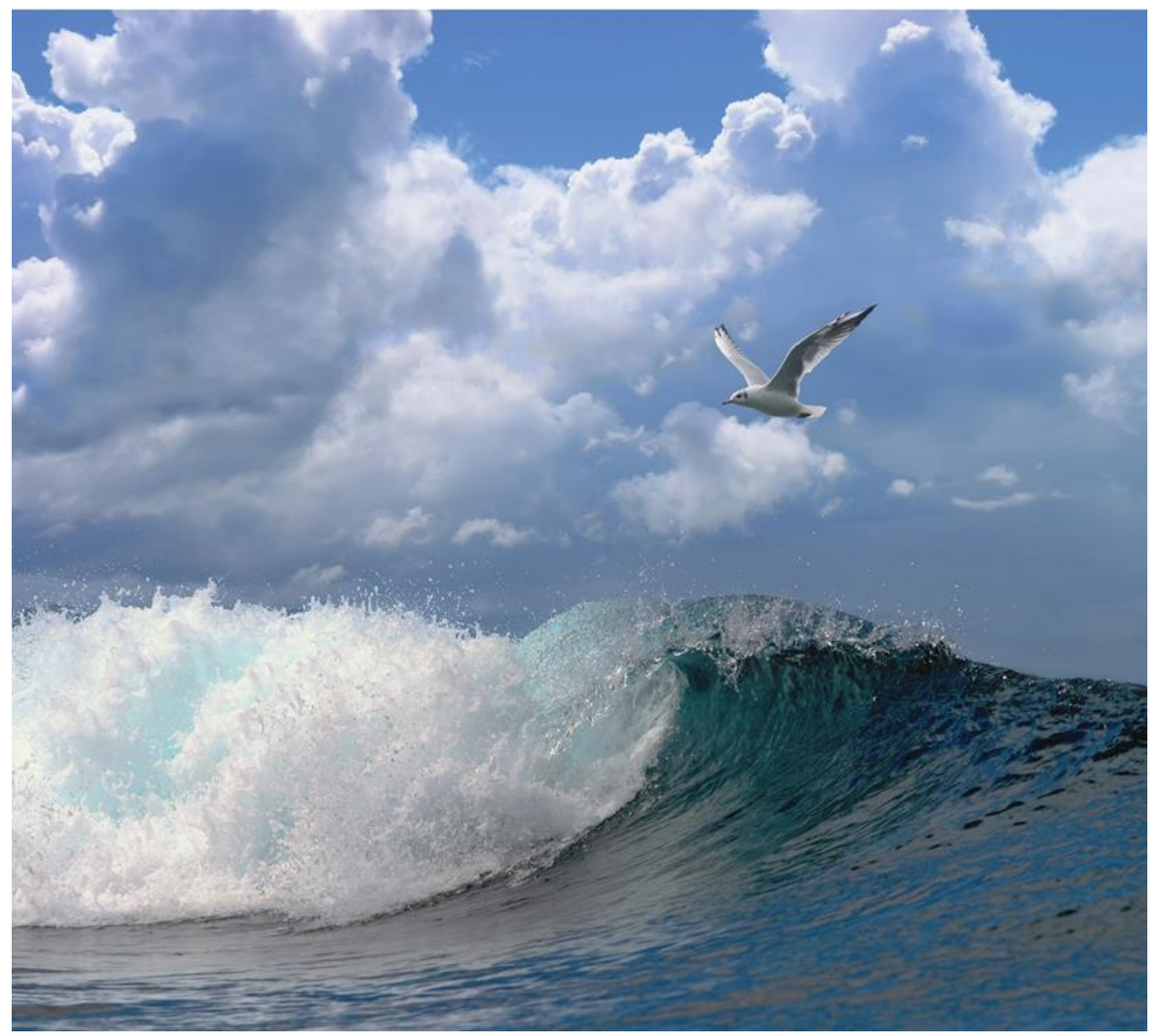

\title{
Evaluatie Vismigratievoorziening Kleine Sluis IJmuiden voor schieraal
}




\section{Evaluatie Vismigratievoorziening Kleine Sluis IJmuiden voor schieraal}

Auteur(s): $\quad$ A.B. Griffioen, D. Burggraaf, O.A. van Keeken, H.V. Winter 
Opdrachtgever: Rijkswaterstaat WNN

T.a.v.: Marco van Wieringen

Toekanweg 7

2035 LC Haarlem

Dit rapport is gratis te downloaden van https://doi.org/10.18174/470887

Wageningen Marine Research verstrekt geen gedrukte exemplaren van rapporten.

Wageningen Marine Research Wageningen UR is ISO 9001:2015 gecertificeerd.

\section{(C) Wageningen Marine Research Wageningen UR}

Wageningen Marine Research, onderdeel van Stichting Wageningen Research KvK nr. 09098104,

IMARES BTW nr. NL 8113.83.696.B16. Code BIC/SWIFT address: RABONL2U IBAN code: NL 73 RABO 0373599285
De Directie van Wageningen Marine Research is niet aansprakelijk voor gevolgschade, noch voor schade welke voortvloeit uit toepassingen van de resultaten van werkzaamheden of andere gegevens verkregen van Wageningen Marine Research opdrachtgever vrijwaart Wageningen Marine Research van aanspraken van derden in verband met deze toepassing.

Dit rapport is vervaardigd op verzoek van de opdrachtgever hierboven aangegeven en is zijn eigendom. Niets uit dit rapport mag weergegeven en/of gepubliceerd worden, gefotokopieerd of op enige andere manier gebruikt worden zonder schriftelijke toestemming van de opdrachtgever. 


\section{Inhoud}

Samenvatting

$\begin{array}{llr}1 & \text { Inleiding } & 6\end{array}$

$\begin{array}{llr}2 & \text { Methoden } & 7\end{array}$

$\begin{array}{llc}2.1 & \text { Studiegebied } & 7\end{array}$

2.2 Werking vismigratievoorziening 8

2.2.1 Algemene werking $\quad 8$

2.2.2 Regeling vismigratievoorziening 2e halfjaar (m.n. visuittrek of 'najaar') 8

2.3 Hydrauliek vismigratievoorziening Kleine Sluis 9

2.4 Merk-terugvangst en akoestische telemetrie 11

2.4.1 Akoestische zenders 11

$\begin{array}{ll}2.4 .2 & \text { Passieve tags }\end{array} 11$

2.5 PIT-tag detectielussen $\quad 12$

2.5.1 Plaatsing detectielussen $\quad 12$

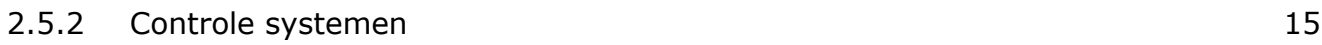

$\begin{array}{llr}3 & \text { Resultaten } & 16\end{array}$

3.1 Verdeling van migratie over het complex 16

3.1.1 Verdeling succesvolle passage sluiscomplex 16

3.1.2 Attractie van Zuidersluis en Kleine Sluis op aal $\quad 18$

3.2 Detecties Kleine Sluis $\quad 18$

$4 \quad$ Discussie en Conclusie $\quad 24$

$\begin{array}{llr}5 & \text { Aanbevelingen } & \mathbf{2 7}\end{array}$

Bijlage: Regeling vismigratievoorziening 1e halfjaar (m.n. visintrek of 'voorjaar') 28

$\begin{array}{llr}6 & \text { Kwaliteitsborging } & 29\end{array}$

$\begin{array}{lr}\text { Literatuur } & 29\end{array}$

$\begin{array}{lr}\text { Verantwoording } & 31\end{array}$ 


\section{Samenvatting}

Via het Noordzeekanaal wordt een groot achterland aan water ontsloten en het sluiscomplex te IJmuiden is hierdoor een belangrijk in- en uittrekpunt voor trekvis. De regionale waterbeheerders Rijkswaterstaat West-Nederland Noord, provincie Noord-Holland, Hoogheemraadschap Hollands Noorderkwartier, Hoogheemraadschap van Rijnland en Waterschap Amstel, Gooi en Vecht-, Sportvisserij MidWest Nederland, Gemeente Amsterdam en Havenbedrijf Amsterdam, zetten zich in voor een goede bereikbaarheid naar de wateren van de regio rondom het Noordzeekanaal voor migrerende vissen. Daarom wordt door deze partijen samengewerkt binnen het project Ecologische Verbindingszone Noordzeekanaal en Ommelanden. In 2017 en 2018 voerden zij een integraal onderzoek uit naar vismigratie gericht op de uittrek van schieraal en de intrek van driedoornige stekelbaars en glasaal. De doelstelling van dit onderzoek was het vaststellen van het aanbod van trekvissen in IJmuiden en langs het Noordzeekanaal, timing en routes van de vissen, evenals het gedrag in de buurt van obstakels, zoals gemalen en schutluizen. Van een aantal vispassages werd de passeerbaarheid onderzocht. De onderzoeken in 2017 en 2018 legden ook de uitgangssituatie voor vismigratie vast met betrekking tot de uitvoering van enkele ingrepen in de infrastructuur in IJmuiden, zoals de bouw van een nieuwe grote zeesluis met antiverziltings-maatregelen en op de langere termijn de vervangingsopgave van het gemaal in IJmuiden.

De huidige studie maakt onderdeel uit van de beschreven onderzoeken en evalueert specifiek de vismigratievoorziening bij de Kleine Sluis te IJmuiden. De kennisvraag van deze studie is als volgt geformuleerd: Wat is de passage-efficiëntie van de vismigratievoorziening in de Kleine Sluis te IJmuiden voor schieraal? De passage-efficiëntie is hierbij gedefinieerd als de verhouding tussen het aantal schieraal dat succesvol de vismigratievoorziening passeert en de omvang van het aanbod ter plaatse.

Bij deze sluis is een voorziening getroffen gericht op de intrek van glasaal en driedoornige stekelbaars en de uittrek van schieraal. De vismigratievoorziening bij de Kleine Sluis maakt gebruik van de rinketten (nivelleringen schuiven in de sluisdeuren) in de kolkdeuren die afhankelijk van het zeepeil geheel of gedeeltelijk worden geopend. De resultaten van andere onderdelen van de overkoepelende studie (akoestisch telemetrie netwerk) zijn ingezet om de vismigratiemaatregel bij de Kleine Sluis te evalueren in verhouding tot de uittrek op andere locaties bij het sluiscomplex. Rondom het complex zijn 14 stuks akoestische VR2W receivers (ontvangers) van VEMCO geplaatst om de verdeling van uittrekkende schieraal uit het Noordzeekanaal vast te leggen.

Om de vismigratie voorziening te evalueren zijn visdetectie systemen geplaatst (PIT-tag lussen) rondom de rinketten geplaatst en zijn landinwaarts, ca. $2 \mathrm{~km}$ vanaf het sluiscomplex, in totaal 1925 schieralen gemerkt met $32 \mathrm{~mm}$ PIT-tags en weer uitgezet. Tevens is er, voor een ander onderdeel binnen de overkoepelende studie, een akoestisch telemetrie netwerk (VEMCO VR2W receivers) geplaatst rondom het sluiscomplex en het Noordzeekanaal en zijn 50 schieralen met een zender (VEMCO V9P) en een 32mm PIT-tag uitgerust op het Noordzeekanaal en een aanvullende 255 schieralen elders in wateren aansluitend op het Noordzeekanaal (V9 en 32mm PIT-tag).

De resultaten van deze studie laten zien dat het gebruik van de vismigratievoorziening bij de Kleine Sluis te IJmuiden, door uittrekkende schieralen beperkt is. Het overgrote deel van de schieralen trekt via de Noordersluis, het spui/gemaal of de Middensluis naar zee (ruim 94\%). Van de schieralen die bij de Kleine Sluis aankomen maakt tussen $4 \%$ en $19 \%$ geheel of gedeeltelijk (combinatie van passage via vismigratievoorziening en tijdens schutting) gebruik van de migratievoorziening om de Kleine Sluis te passeren. In het maximale geval $(19 \%)$ is er van uit gegaan dat alle gedetecteerde schieralen ook daadwerkelijk de vismigratievoorziening zijn gepasseerd, dit kan op basis van de gegevens niet worden uitgesloten. Ca. $80 \%$ van de schieralen die bij de sluis aankomen, keren uiteindelijk om en vervolgen elders via het complex hun weg richting zee. 
Op basis van de telemetrie gegevens (VEMCO) is gebleken dat er een beperkte aantrekkende werking richting Kleine Sluis is, mogelijk ten gevolge van de instroom van zeewater via de vismigratie voorziening. Op het niveau van het gehele complex zal dit echter niet van betekenis zijn.

De eindconclusie van deze studie is dat schieraal beperkt wordt aangetrokken naar de locatie van de vismigratie voorziening (ca. 6\%) en dat van de schieralen die zich aandienen 4-19\% geheel of gedeeltelijk gebruikt maakt van de voorziening. 


\section{$1 \quad$ Inleiding}

Via het Noordzeekanaal wordt een groot achterland aan water ontsloten en het sluiscomplex te IJmuiden is hierdoor een belangrijk in- en uittrekpunt voor trekvis zoals schieraal. De regionale waterbeheerders -Rijkswaterstaat West-Nederland Noord, provincie Noord-Holland, Hoogheemraadschap Hollands Noorderkwartier, Hoogheemraadschap van Rijnland en Waterschap Amstel, Gooi en Vecht-, Sportvisserij MidWest Nederland, Gemeente Amsterdam en Havenbedrijf Amsterdam, zetten zich in voor een goede bereikbaarheid naar de wateren van de regio rondom het Noordzeekanaal voor migrerende vissen. Daarom wordt door deze partijen samengewerkt binnen het project Ecologische Verbindingszone Noordzeekanaal en Ommelanden. In 2017 en 2018 voerden zij een integraal onderzoek uit naar vismigratie gericht op de uittrek van schieraal en de intrek van driedoornige stekelbaars en glasaal. De doelstelling van het overkoepelende onderzoek is het vaststellen van het aanbod van trekvissen in IJmuiden en langs het Noordzeekanaal, timing en routes van de vissen, evenals het gedrag in de buurt van obstakels, zoals gemalen en schutluizen. Van een aantal vispassages werd de passeerbaarheid onderzocht. De onderzoeken in 2017 en 2018 legden ook de uitgangssituatie voor vismigratie vast met betrekking tot de uitvoering van enkele ingrepen in de infrastructuur in IJmuiden, zoals de bouw van een nieuwe grote zeesluis met antiverziltingsmaatregelen en op de langere termijn de vervangingsopgave van het gemaal in IJmuiden.

De huidige studie maakt onderdeel uit van het overkoepelende onderzoek en evalueert specifiek de vismigratievoorziening bij de Kleine Sluis te IJmuiden ten behoeve van de uittrek van schieraal richting zee. De kennisvraag van deze studie is als volgt geformuleerd: Wat is de passageefficiëntie van de vismigratievoorziening in de Kleine Sluis te IJmuiden voor schieraal? De passage-efficiëntie is hierbij gedefinieerd als de verhouding tussen het aantal schieraal dat succesvol de vismigratievoorziening passeert en de omvang van het aanbod ter plaatse.

Voorafgaand aan deze studie zijn er al diverse onderzoeken uitgevoerd naar de uittrek van schieraal (Griffioen et al. 2017, Griffioen and Winter 2017). In het najaar van 2016 werd een onderzoek gedaan naar de uittrek van schieraal middels fuikenmonitoring en een merk-terugvangst experiment met PITtags $^{1}$ (Griffioen and Winter 2017). Op basis van dit onderzoek is met behulp van de Lincoln-Petersen methode geschat dat er gedurende 2 september - 15 december $2016110.000 \pm 12.000$ schieralen via het sluizencomplex bij IJmuiden vanuit het Noordzeekanaal naar zee zijn getrokken. Dit aantal is vergelijkbaar met schattingen van aantallen uitgetrokken schieralen in eerdere onderzoeken in 2007 en 2008 (Winter 2011). De uittrek van schieraal via het Noordzeekanaal bij IJmuiden maakt daarmee ca. $10 \%$ uit van het landelijke bestand aan schieraal dat succesvol naar zee trekt.

In het najaar van 2017 is door het samenwerkingsverband een grootschalig opgezet onderzoek uitgevoerd naar het migratiesucces en -gedrag van schieraal tussen polder-/boezemwateren en het Noordzeekanaal, waarbij gebruik wordt gemaakt van PIT-tags en akoestische telemetrie (VEMCO). De rapportage hiervan is in voorbereiding. In aansluiting op dit onderzoek is in dezelfde periode een onderzoek opgezet gericht op het gebruik van de vismigratievoorziening (vispassage) in de Kleine Sluis IJmuiden door schieraal. Deze voorziening is in april 2017 opgeleverd en bestaat uit een automatische regeling van de rinketschuiven, als er niet geschut wordt, gericht op de uittrek van schieraal (najaar) en de intrek van glasaal en driedoornige stekelbaars (voorjaar). Door alle rinketten te voorzien van antenneloops is de passage van met PIT-tags gemerkte aal geregistreerd. Bij de analyse van de resultaten wordt ook gebruik gemaakt van de voorlopige resultaten van de akoestische telemetrie van het grootschaliger onderzoek. Dit onderzoek is uitgevoerd in samenwerking met Visserij Service Nederland (fuiken en taggen), VisAdvies (advies PIT-tag) en WALS diving (plaatsing detectielussen).

\footnotetext{
${ }^{1}$ Passive Integrated Transponder
} 


\section{$2 \quad$ Methoden}

\section{$2.1 \quad$ Studiegebied}

Deze studie is uitgevoerd in IJmuiden bij de Kleine Sluis. Deze sluis maakt onderdeel uit van een groter sluiscomplex van 4 schutsluizen, 1 spuisluiscomplex en een gemaal (Figuur 2-1). Rondom het complex zijn 14 stuks akoestische VR2W receivers (ontvangers) van VEMCO geplaatst om de verdeling van uittrekkende schieraal uit het Noordzeekanaal vast te leggen ${ }^{2}$. De Kleine Sluis ligt aan de zuidkant van het complex en is een sluis van ca. $111 \mathrm{~m}$ lang, $11 \mathrm{~m}$ breed en NAP -3,75m diep (Figuur 2-2). De sluis deelt met de naastgelegen Zuidersluis een Buiten- en een Binnentoeleidingskanaal van resp. $230 \mathrm{~m}$ en $645 \mathrm{~m}$.

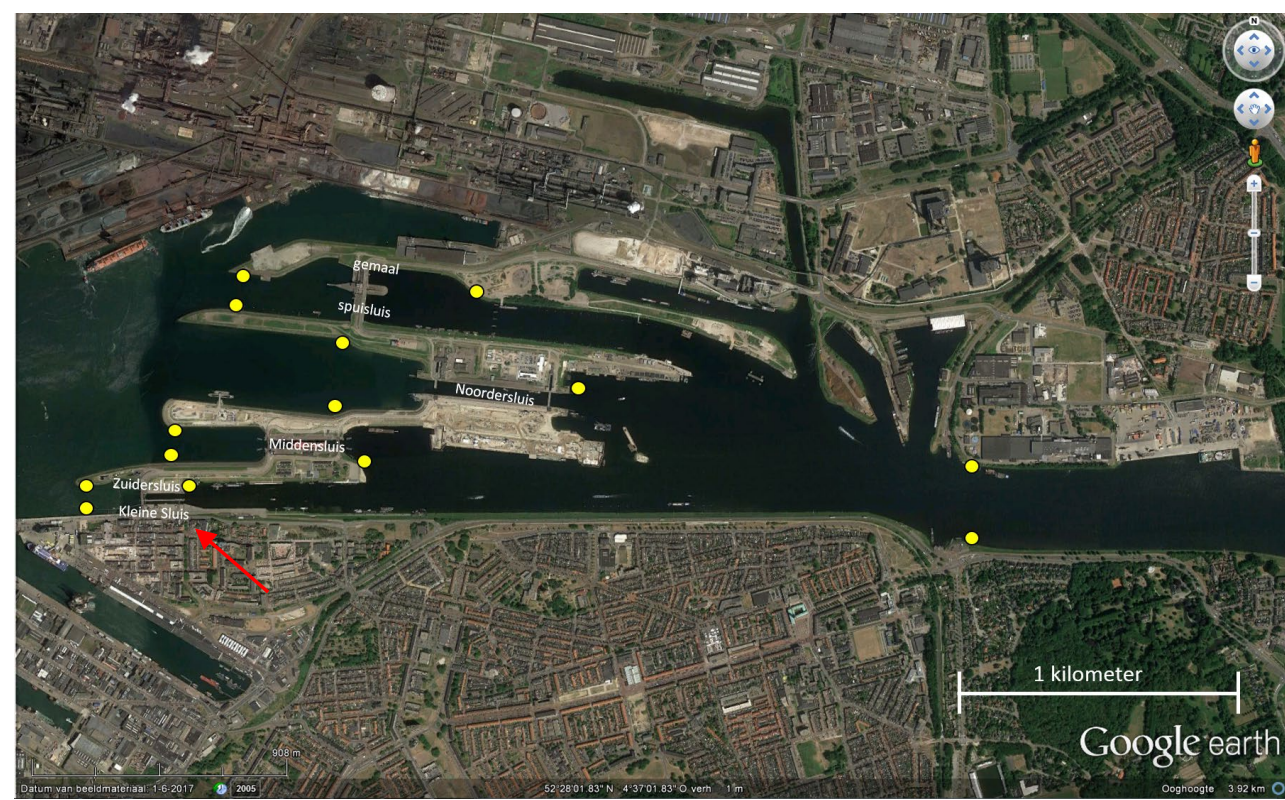

Figuur 2-1 Gebiedsoverzicht sluiscomplex te IJmuiden en plaatsing van 14 stuks receivers van het "VEMCO"-netwerk rondom de sluizen

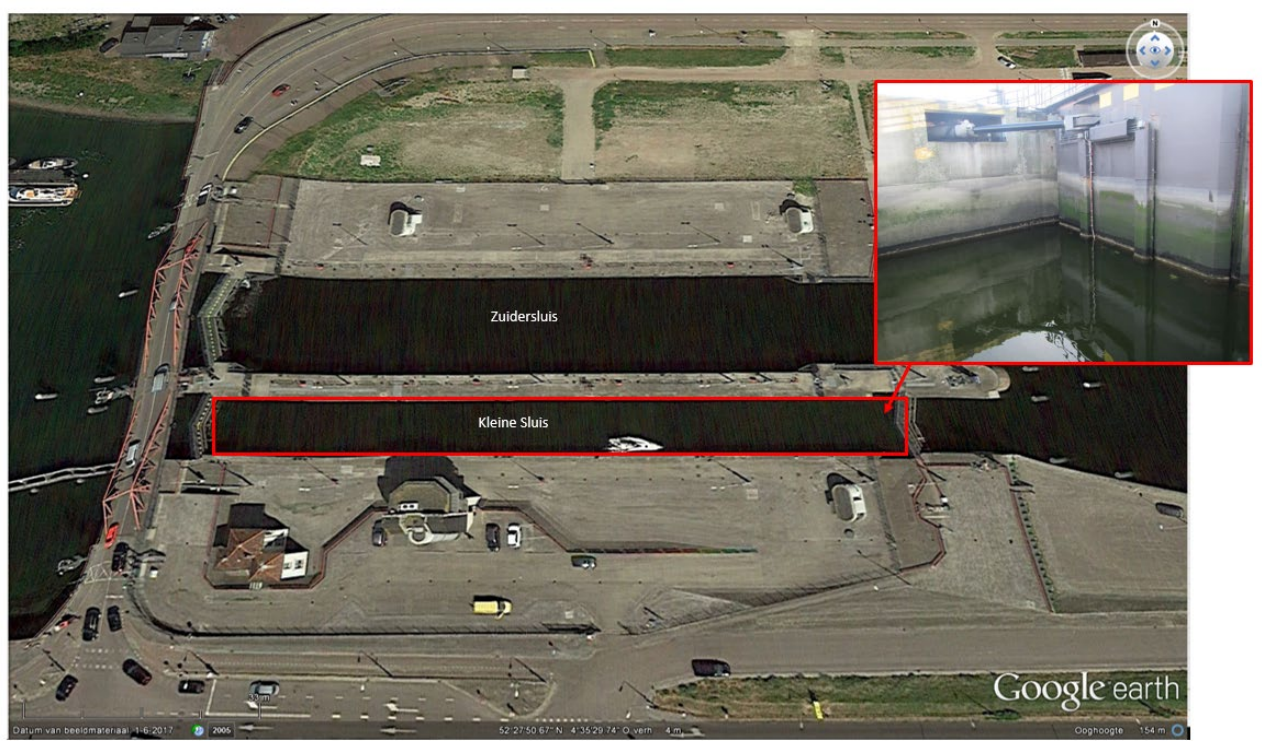

Figuur 2-2 Gebiedsoverzicht Kleine Sluis te IJmuiden. Bij deze sluis is een vismigratievoorziening toegepast d.m.v. aangepast rinketten beheer

\footnotetext{
${ }^{2}$ Dit netwerk maakt onderdeel uit van een netwerk van 64 receivers in en rondom het Noordzeekanaal (zie inleiding)
} 


\section{$2.2 \quad$ Werking vismigratievoorziening}

\subsubsection{Algemene werking}

De vismigratievoorziening functioneert met behulp van een automatische regeling van de rinketschuiven in de sluisdeuren (een paar rinketten per deur, vier deuren). Als er niet geschut wordt gaat de kolk halfautomatisch over op de ingestelde regeling voor vismigratie. Er is zowel een intrekals een uittrekstand. De intrekstand ( $1^{\mathrm{e}}$ halfjaar) is actief vanaf 1 februari tot aan 1 augustus, en de uittrekstand ( $2^{\mathrm{e}}$ halfjaar) van 1 augustus tot aan 1 februari. In deze rapportage wordt de uittrek van schieraal beoordeeld middels gemerkte schieralen. Voor de volledigheid wordt ook de intrekstand beschreven in de bijlage. Onderstaande beschrijving is volgens het ontwerp. Het werkelijk (hydraulisch) functioneren van de vismigratievoorziening wordt beschreven in paragraaf 2.3. De vismigratievoorziening regeling gaat uit van enkele basisinstellingen (Tabel 1 ).

Tabel 1 Basisinstellingen van de Kleine Sluis in de periode 5 juli 2017-12 maart 2018

\begin{tabular}{|c|c|c|c|}
\hline instelling * & * waarde & wijzigingen vanaf 3 november 2017 & eenheid \\
\hline Rusttijd vispassage & 180 & & $\mathrm{sec}$ \\
\hline Activeringstijd vispassage & 60 & & $\mathrm{sec}$ \\
\hline Laag niveau vergrendeling & $-1,4$ & & mNAP \\
\hline Hoog niveau vergrendeling & 1,9 & & mNAP \\
\hline Tijd laagwater & 0 & 600 & sec \\
\hline Offset laagwater & 0 & & $\mathrm{~m}$ \\
\hline Tijd hoogwater & 300 & 600 & $\mathrm{sec}$ \\
\hline Offset hoogwater & 0 & & $\mathrm{~m}$ \\
\hline Tijd hoogwater deel 2 & 1800 & & $\mathrm{sec}$ \\
\hline Offset hoogwater deel 2 & 0,15 & & $\mathrm{~m}$ \\
\hline Niveau hoogwater deel 2 & 0,5 & & mNAP \\
\hline Sample tijd dalend & 900 & & $\mathrm{sec}$ \\
\hline Hysteresis zeepeil dalend in & $-0,02$ & & $\mathrm{~m}$ \\
\hline Hysteresis zeepeil dalend uit & 0,04 & & $\mathrm{~m}$ \\
\hline $\begin{array}{l}\text { * Rusttijd vismigratievoorziening } \\
\text { Activeringstijd vismigratievoorziening } \\
\text { Laag niveau vergrendeling } \\
\text { Hoog niveau vergrendeling } \\
\text { Tijd laagwater } \\
\text { Offset laagwater } \\
\text { Tijd hoogwater } \\
\text { Offset hoogwater } \\
\text { Tijd hoogwater deel } 2 \\
\text { Offset hoogwater deel } 2 \\
\text { Niveau hoogwater deel } 2 \\
\text { Sample tijd dalend } \\
\text { Hysteresis zeepeil dalend in } \\
\text { Hysteresis zeepeil dalend uit }\end{array}$ & $\begin{array}{l}\text { duur na schut } \\
\text { duur melding } \\
\text { laagwaterstan } \\
\text { hoogwatersta } \\
\text { duur na bereil } \\
\text { vermeerderin } \\
\text { duur na bereil } \\
\text { vermeerderin } \\
\text { duur na bereil } \\
\text { vermeerderin } \\
\text { buitenwaterst } \\
\text { periode waarc } \\
\text { benodigd nive } \\
\text { benodigd nive }\end{array}$ & $\begin{array}{l}\text { en tot start activeringstijd } \\
\text { vismigratievoorziening start over ... sec.' bedienscher } \\
\text { d waarbij vismigratievoorziening sluit } \\
\text { nd waarbij vismigratievoorziening sluit } \\
\text { en gelijkwater bij eb voor overgang naar fase LW } \\
\text { niveau voor faseovergang naar LW } \\
\text { en gelijkwater bij vloed voor overgang naar fase HW1 } \\
\text { niveau voor faseovergang naar HW1 } \\
\text { en buitenwaterstand niveau HW2 tijdens eb voor ove } \\
\text { niveau voor faseovergang naar HW2 } \\
\text { and tijdens eb waarbij fase HW1 overgaat in fase HW } \\
\text { ver dalend peil wordt vastgesteld } \\
\text { auverschil voor vaststelling eb } \\
\text { auverschil voor vaststelling vloed }\end{array}$ & $\begin{array}{l}11 \\
\text { /ergang naar fase HW2 } \\
\text { V2 }\end{array}$ \\
\hline
\end{tabular}

\subsubsection{Regeling vismigratievoorziening $2 e$ halfjaar (m.n. visuittrek of 'najaar')}

De vismigratievoorziening regeling kent 3 fasen. Deze fasen zijn opeenvolgend en afhankelijk van het waterpeil aan de zeezijde (buitenwater). De laagwaterfase (LW), is de fase wanneer het buitenwaterpeil (zeezijde) lager is dan het peil aan de NZK-zijde. De schuiven van de rinketten worden aan beide zijden opengezet (50\% t.o.v. volledige opening) en het NZK-water stroomt naar de zee toe. Schieraal kan via de rinketten de sluis bereiken en eventueel gelijk doorzwemmen richting de zee. De hoogwaterfase 1 (HW1) start wanneer het buitenwaterpeil (zeezijde) gelijk is aan het NZK-peil en vanaf dat moment, door opkomend water, stijgt tot het moment van hoogwaterpeil. Om te voorkomen dat er teveel water richting het NZK stroomt én toch een zoute lokstroom te creëren staan de schuiven aan de zeezijde dicht behalve de meest zuidelijke schuif. Deze staat voor 10\% open. Aan de NZK-zijde is alleen de meest zuidelijke schuif volledig open gezet (100\%). Hoogwaterfase 2 (HW2), in deze fase worden de vissen de gelegenheid geboden uit de kolk richting zee te zwemmen en wordt ook de laatste schuif aan de kanaalzijde dichtgezet. Hierdoor kunnen de schuiven aan de zeezijde nu allemaal open worden gezet (100\%). Het water stroomt zowel in de sluis (zout) als uit de sluis (zoet/brak) door het verschil in gewicht van het water (zie Figuur 2-4 rechtsonder). De eerste twee fasen duren volgens het ontwerp gemiddeld ca. 4 uur en fase HW2 ca. 4,5 uur. 


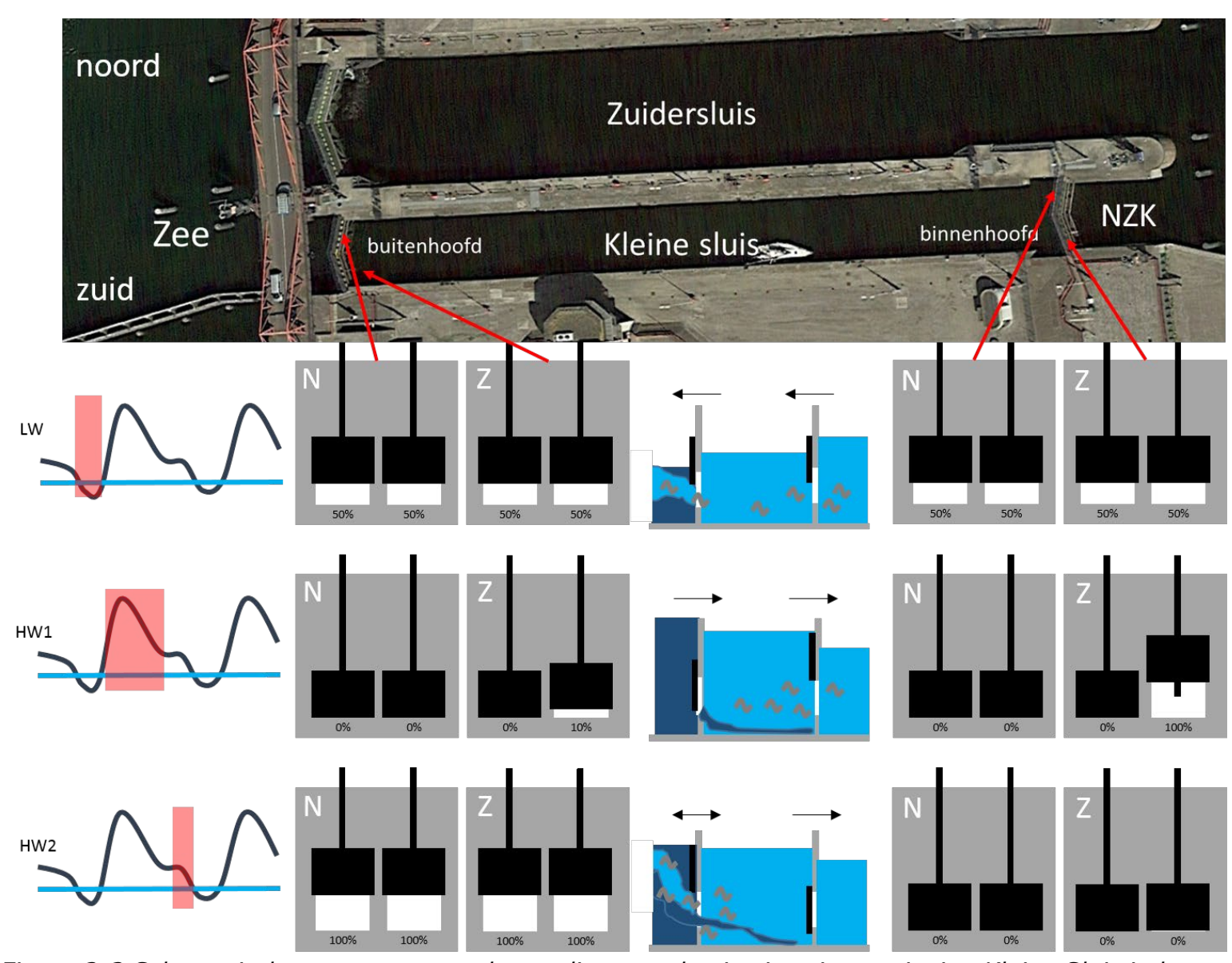

Figuur 2-3 Schematische weergave van de regeling van de vismigratievoorziening Kleine Sluis in het $2^{e}$ halfjaar, tijdens de uittrek van schieraal. $L W=$ laagwater HW1 = Hoogwater fase $1, H W 2=$ Hoogwater fase 2.

\subsection{Hydrauliek vismigratievoorziening Kleine Sluis}

De datamonitoring van de vismigratievoorziening betreft onder meer de fase waarin de vismigratievoorziening zich bevindt en een registratie van het in- en uitgaande debiet. Dit laatste wordt berekend aan de hand van een nog niet geijkte afvoerformule, waarbij gebruik wordt gemaakt van het verval over de buitendeuren en de geregistreerde schuifstanden van de rinketten in de buitendeuren. Bij de debietberekening is uitgegaan van een afvoer coëfficiënt voor de zeewaartse stroming van 0,8 en voor de kanaalwaartse stroming van 0,75 (Jongeling 2012) en dat er enkel wateruitwisseling via de rinketten plaatsvindt. In Tabel $2 a b$ is de dataregistratie voor de periode oktober-december 2017 weergegeven (Tabel 2a) en de ontwerpberekeningen van de vismigratievoorziening (Tabel $2 b$ ).

Het kanaalwaarts debiet tijdens fase HW1 blijkt veel hoger dan volgens de ontwerpberekening. Ook tijdens HW2, waarbij alle rinketten aan het binnenhoofd gesloten zijn en alle rinketten aan het buitenhoofd geopend, was een hoog instromend debiet berekend aan de hand van de registraties. Dit wijst op lekkage van de deuren aan het binnenhoofd, hetgeen ook in deze PIT-tag studie is geconstateerd. Aan de onderzijde van een van de deuren was door een verbogen plaat een opening van ca. $30 \mathrm{~cm}$ bij 1,5m breed ontstaan. Zo'n lekkage was ook aan het buitenhoofd aanwezig.

De 25-percentiel waarden geven de stroomsnelheden aan door de rinketten waarbij een kwart van de metingen lager scoort. Volgens Tabel 2a zal tijdens HW1, waarbij één rinket aan het binnenhoofd geheel geopend is en een rinket aan het buitenhoofd op een kier staat (Figuur 2-3), gedurende het grootste gedeelte van de tijd moeite ondervinden om de kolk in te zwemmen (25-percentiel kanaalwaartse stroming via rinket binnenhoofd is $1,84 \mathrm{~m} / \mathrm{s}$ ). 
De instelling van de vismigratie voorziening is gebaseerd op kengetallen uit Klein Bretelaar (2005), die uitgaat van een sprintsnelheid van gedurende $20 \mathrm{sec}$ van ca. 1,45m/s $(70 \mathrm{~cm}$ aal) en Clough et al. (2004) waar een gemiddelde sprintsnelheid is vastgesteld van $1,5 \mathrm{~m} / \mathrm{s}(50-70 \mathrm{~cm}$ aal).

Tijdens HW2, waarbij alle rinketten aan het binnenhoofd geopend zijn (Figuur 2-3) en alle rinketten aan het buitenhoofd gesloten zijn, zijn de stromingen bij het buitenhoofd zo hoog dat de alen niet de mogelijkheid zullen hebben de kolk te verlaten (25-percentiel is 2,56 m/s). Tijdens LW kunnen de alen meestromen naar zee, deze fase duurt echter veel minder lang dan volgens het ontwerp is ingeschat, daarbij komt dat gedurende een groot deel van de laagwater-fase (43\%) toch met grote snelheid water kanaalwaarts stroomt. Uit de gegevens valt af te leiden dat de LW-fase te vroeg inzet en te laat eindigt, wat te maken heeft met de basisinstellingen (Tabel 1).

Een en ander heeft natuurlijk grote invloed op de wijze waarop de schieralen gebruik kunnen maken van de vismigratievoorziening.

Tabel 2a en $2 b$ Geregistreerde hydraulische gegevens van de vismigratievoorziening Kleine Sluis in de periode oktober-december 2017 (a) en berekende gegevens aan de hand van het ontwerp (b). IN: kanaalwaarts, UIT: zeewaarts.

\begin{tabular}{|c|c|c|c|c|c|}
\hline \multirow{2}{*}{$\begin{array}{l}\text { a) Dataregistratie } \\
\text { oktober-december } 2017\end{array}$} & \multirow[b]{2}{*}{ totaal } & \multicolumn{4}{|c|}{ Vispassage-mode } \\
\hline & & schutting/uit & LW & HW1 & HW2 \\
\hline gem. debiet UIT (m3/s) & 0,48 & - & 0,47 & 0,00 & 0,00 \\
\hline gem. debiet IN (m3/s) & $-6,29$ & $-0,00$ & $-0,28$ & $-2,06$ & $-3,95$ \\
\hline netto debiet $(\mathrm{m} 3 / \mathrm{s})$ & $-5,81$ & $-0,00$ & 0,20 & $-2,06$ & $-3,95$ \\
\hline netto richting & kanaal & kanaal & zee & kanaal & kanaal \\
\hline tijdsduur UIT (s) & 142.800 & - & 136.000 & 5.400 & 1.400 \\
\hline tijdsduur IN (s) & 1.888 .800 & 11.600 & 104.000 & 1.154 .800 & 616.600 \\
\hline tijdsduur nulwaarde (s) & 619.800 & 618.800 & 400 & 400 & 200 \\
\hline verdeling fases & $100 \%$ & $24 \%$ & $9 \%$ & $44 \%$ & $23 \%$ \\
\hline UIT buitenhoofd gem. v (m/s) & - & & 2,82 & 24,69 & 0,51 \\
\hline UIT buitenhoofd 25 percentiel $(\mathrm{m} / \mathrm{s})$ & - & & 2,00 & 20,67 & 0,46 \\
\hline UIT binnenhoofd gem. $v(\mathrm{~m} / \mathrm{s})$ & - & & 2,82 & 2,54 & - \\
\hline UIT binnenhoofd 25 percentiel $(\mathrm{m} / \mathrm{s})$ & - & & 2,00 & 2,13 & - \\
\hline UIT kolk gem. v (m/s) & - & & 0,23 & 0,11 & 0,09 \\
\hline UIT kolk 25 percentiel (m/s) & - & & 0,17 & 0,09 & 0,08 \\
\hline IN buitenhoofd gem. $v(\mathrm{~m} / \mathrm{s})$ & - & & $-2,18$ & $-27,80$ & $-2,58$ \\
\hline IN buitenhoofd 25 percentiel $(\mathrm{m} / \mathrm{s})$ & - & & $-1,38$ & $-17,90$ & $-2,56$ \\
\hline IN binnenhoofd gem. v (m/s) & - & & $-2,18$ & $-2,86$ & - \\
\hline IN binnenhoofd 25 percentiel (m/s) & - & & $-1,38$ & $-1,84$ & - \\
\hline IN kolk gem. v (m/s) & - & & $-0,18$ & $-0,12$ & $-0,43$ \\
\hline IN kolk 25 percentiel $(\mathrm{m} / \mathrm{s})$ & - & & $-0,11$ & $-0,08$ & $-0,42$ \\
\hline
\end{tabular}

\begin{tabular}{|c|c|c|c|c|c|}
\hline \multirow{2}{*}{$\begin{array}{l}\text { b) Berekend adhv het ontwerp } \\
\text { Uittrek (aug-jan) }\end{array}$} & \multirow[b]{2}{*}{ totaal } & \multicolumn{4}{|c|}{ Vispassage-fase } \\
\hline & & schutting/uit & LW & HW1 & HW2 \\
\hline gem. debiet UIT $(\mathrm{m} 3 / \mathrm{s})$ & 2,83 & & 2,83 & & \\
\hline gem. debiet IN (m3/s) & $-0,44$ & & & $-0,44$ & - \\
\hline netto debiet $(\mathrm{m} 3 / \mathrm{s})$ & 2,40 & - & 2,83 & $-0,44$ & - \\
\hline netto richting & zee & & zee & kanaal & \\
\hline tijdsduur UIT (s) & 674.230 & & 674.230 & & \\
\hline tijdsduur IN (s) & 1.348 .460 & & & 674.230 & 674.230 \\
\hline tijdsduur nulwaarde (s) & 618.800 & 618.800 & & & \\
\hline verdeling fases & $100 \%$ & $24 \%$ & $25 \%$ & $25 \%$ & $25 \%$ \\
\hline UIT buitenhoofd gem. v (m/s) & & & 0,86 & & \\
\hline UIT buitenhoofd 25 percentiel $(\mathrm{m} / \mathrm{s})$ & & & 0,57 & & \\
\hline UIT binnenhoofd gem. v (m/s) & & & 0,86 & & \\
\hline UIT binnenhoofd 25 percentiel $(\mathrm{m} / \mathrm{s})$ & & & 0,57 & & \\
\hline UIT kolk gem. v (m/s) & & & 0,08 & & \\
\hline UIT kolk 25 percentiel (m/s) & & & 0,05 & & \\
\hline IN buitenhoofd gem. $v(\mathrm{~m} / \mathrm{s})$ & & & & $-2,65$ & \\
\hline IN buitenhoofd 25 percentiel (m/s) & & & & $-1,87$ & \\
\hline IN binnenhoofd gem. v (m/s) & & & & $-0,26$ & \\
\hline IN binnenhoofd 25 percentiel $(\mathrm{m} / \mathrm{s})$ & & & & $-0,19$ & \\
\hline IN kolk gem. v (m/s) & & & & $-0,01$ & \\
\hline IN kolk 25 percentiel (m/s) & & & & $-0,01$ & \\
\hline
\end{tabular}

De vismigratievoorziening is in de periode oktober-december 2017 voor $76 \%$ van de tijd actief geweest. In de donkere uren was dit gemiddeld $83 \%$ en overdag, als er meer geschut werd, was dit $65 \%$. Van de actieve uren was $67 \%$ tussen zonsondergang en -opgang. Schieraal is in IJmuiden 
vooral actief tussen zonsondergang en -opgang, wat bleek uit onderzoek met $2 \mathrm{~d}$-telemetrie voor het spui/gemaal in 2009 en 2010, waarbij 85\% (spui) tot 95\% (gemaal) van de detecties in de donkere uren plaatsvond (Vis et al 2010).

\subsection{Merk-terugvangst en akoestische telemetrie}

\subsubsection{Akoestische zenders}

Om de effectiviteit van de passage te beoordelen is het van belang te weten welk deel van de aal wordt aangetrokken door de Zuidersluis/Kleine Sluis en uiteindelijk (succesvol) gebruik maakt van de Zuidersluis/Kleine Sluis ten opzichte van de andere sluizen/gemaal/spui. Om deze verdeling van uittrekkende schieraal over het sluiscomplex te IJmuiden te bepalen zijn 50 schieralen met een akoestische zender (VEMCO V9P, delay 30-50sec) uitgerust. De schieralen zijn gevangen bij het sluiscomplex met fuiken in het Noordzeekanaal en gemerkt en te water gelaten voorbij de veerpont op ca. 2-3km vanaf het sluis complex op vijf dagen: 16, 19 en 23 oktober en op 6 en 13 november 2017. Er zijn per dag 10 schieralen gemerkt om de variatie aan omstandigheden (weer, afvoer, etc.) te verdelen over de tijd (Tabel 3). Tevens zijn er verderop op het NZK en aangrenzende wateren, ook alen gezenderd met een VEMCO V9 $\left(n=255^{3}\right)$. De detecties van deze alen bij het sluiscomplex te IJmuiden worden ook meegenomen in deze studie. De zenders zijn onder WoD vergunning (AVD401002016613) middels een insnede $(2-3 \mathrm{~cm})$ onder verdoving $(0,9 \mathrm{ml} / \mathrm{L} 2$-phenoxy ethanol) ingebracht in de buikholte. De zender geeft elke 30-50 seconde een unieke code af van 8 pulsen. Deze pulsen worden opgevangen door een netwerk van receivers (type VR2W) die in het studie gebied zijn geplaatst (Figuur 2-2). De receivers aan weerszijden van de Kleine Sluis kunnen geen onderscheid maken tussen migratie via de Kleine of via de Zuidersluis. Vandaar dat deze methode de passage beoordeelt van beide sluizen gecombineerd.

\subsubsection{Passieve tags}

Naast de akoestische zenders, zijn er ook passieve tags gebruikt (PIT-tag). Deze tags worden geactiveerd als deze in een magnetisch veld terecht komen. Na activatie geven de tags een unieke code af die wordt opgeslagen op een logger. In deze studie zijn 1925 schieralen met alleen een 32mm PTI tag (HDX, Oregon) onder verdoving $(0,5 \mathrm{ml} / \mathrm{L} 2$-phenoxy ethanol) uitgerust in de buikholte met een 'injector' en naald (vergunning AVD401002016613). De schieralen die met een VEMCO zender zijn uitgerust hebben ook een PIT-tag gekregen (32mm). In totaal zijn er op het Noordzeekanaal dus 1975 schieralen uitgerust met een 32mm PIT-tag (Tabel 3).

De schieralen zijn nadat ze waren bijgekomen van de ingrepen waarbij de akoestische zenders en of de passieve tags zijn ingebracht, teruggezet ter hoogte van de veerpont te Velsen (ca. 2,6 km. van de Kleine Sluis) aan ofwel de noordkant of de zuidkant van het Noordzeekanaal.

\footnotetext{
${ }^{3}$ Er zijn in een overkoepelende studie 330 alen met een V9 VEMCO transmitter (zender) uitgerust. Van deze alen zijn er 50 op het Noordzeekanaal (NZK) zelf en 25 nabij gemaal Katwijk gevangen en weer uitgezet. De herkomst en terugplaatsing van de resterende 305 alen is: Markermeer $(n=25)$, Overtoom $(n=25)$, Kadoelen $(n=25)$, Willem I $(n=25)$, Wilhelminasluis $(n=25)$, Halfweg $(n=25)$, Spaarndam $(n=25)$, Kortenhoef $(n=40)$, Vinkeveen $(n=40)$.
} 
Tabel 3 Overzicht van de gebruikte schieralen op het Noordzeekanaal. De tabel geeft aan of de vissen zijn gemerkt met enkel PIT-tag $(n=1925)$ of zowel PIT-tag als VEMCO V9P zender $(n=50)$. Ook is het aantal per groep, de datum van vangst, operatie en uitzet, de lengte, de locatie van uitzet (noordkant of de zuidkant van het Noordzeekanaal)en het aantal terugvangsten van de betreffende groep.

\begin{tabular}{|c|c|c|c|c|c|c|c|c|}
\hline & VEMCO & & & minimale le & maximale lengte & gemiddelde lengte & itzet & terugvangst $(\mathrm{n})$ \\
\hline $16 /$ okt/17 & & $32 \mathrm{~mm}$ & 99 & 38 & 96.5 & 63.2 & zuid & 1 \\
\hline $16 /$ okt/17 & V9P & $32 \mathrm{~mm}$ & 10 & 66 & 82.2 & 74.9 & suid & 0 \\
\hline 19/okt/17 & & $32 \mathrm{~mm}$ & 35 & 39.2 & 84.4 & 62.3 & zuid & 2 \\
\hline 19/okt/17 & V9P & $32 \mathrm{~mm}$ & 10 & 53.7 & 82.7 & 71.9 & zuid & 2 \\
\hline 23/okt/17 & & $32 \mathrm{~mm}$ & 97 & 36.5 & 95.5 & 65.8 & zdui & 3 \\
\hline 23/okt/17 & V9P & $32 \mathrm{~mm}$ & 10 & 69.6 & 86 & 79.4 & zuid & 1 \\
\hline 26/okt/17 & & $32 \mathrm{~mm}$ & 93 & 37.8 & 95.8 & 71.8 & 3 noord & 4 \\
\hline $30 /$ okt/17 & & $32 \mathrm{~mm}$ & 42 & 39 & 99.5 & 67.4 & zuid & 1 \\
\hline $6 /$ nov/17 & & $32 \mathrm{~mm}$ & 161 & 36 & 98.5 & 70.7 & noord & 2 \\
\hline $6 /$ nov/17 & V9P & $32 \mathrm{~mm}$ & 10 & 70.1 & 96 & 84.5 & noord & 0 \\
\hline 9/nov/17 & & $32 \mathrm{~mm}$ & 170 & 34.5 & 97.6 & 70.3 & zuid & 10 \\
\hline $13 /$ nov/17 & & $32 \mathrm{~mm}$ & 283 & 50.4 & 97.3 & 71.2 & noord & 5 \\
\hline $13 /$ nov/17 & V9P & $32 \mathrm{~mm}$ & 10 & 77.2 & 91.8 & 84.7 & noord & 1 \\
\hline $15 /$ nov/17 & & $32 \mathrm{~mm}$ & 275 & 37.1 & 99 & 71 & zuid & 16 \\
\hline $16 /$ nov/17 & & $32 \mathrm{~mm}$ & 297 & 36.7 & 97.2 & 70.7 & noord & 17 \\
\hline $20 /$ nov/17 & & $32 \mathrm{~mm}$ & 118 & 40.4 & 98.6 & 72.1 & zuid & 6 \\
\hline $23 /$ nov/17 & & $32 \mathrm{~mm}$ & 255 & 36.7 & 99.1 & 72.9 & noord & 6 \\
\hline \begin{tabular}{|l|} 
TOTAAL \\
\end{tabular} & & & 1975 & 34.5 & 99.5 & 70.6 & & 77 \\
\hline
\end{tabular}

\subsection{PIT-tag detectielussen}

\subsubsection{Plaatsing detectielussen}

Bij de Kleine Sluis zijn PIT-tag lussen aangebracht rondom de rinketten van de deuren (Foto 1-6). Op deze manier worden de schieralen die gebruik maken van de passage gedetecteerd wanneer zij via de rinketten de sluisdeuren passeren. Voorafgaand aan de plaatsing van de lussen is op het land een vergelijkbare detectielus getest. Uit deze test bleek dat zowel een $23 \mathrm{~mm}$ als een $32 \mathrm{~mm}$ tag voldoende bereik had voor de afmeting van de detectielussen. Echter, door het gewapende beton, ijzeren deuren en het zoute milieu is ervoor gekozen om te werken met de $32 \mathrm{~mm}$ tags in verband met een groter bereik. Het bereik van de detectielussen is ook in het veld getest. De antennes zijn zo ontworpen dat de sluis volledig operationeel was gedurende het project en dat het risico op schade door scheepvaart nihil was. Om deze reden zijn de antennes geplaatst aan de zijde van de deur die tegen de kade aan valt als de deuren van de sluis werden open gezet, wat tevens de zijde is waar de schuiven zich bevinden. De lussen zijn geplaatst door professionele duikers (WALS) in september en oktober 2017. De lussen waren gereed voordat de schieralen werden gemerkt en losgelaten (16 oktober 2017).

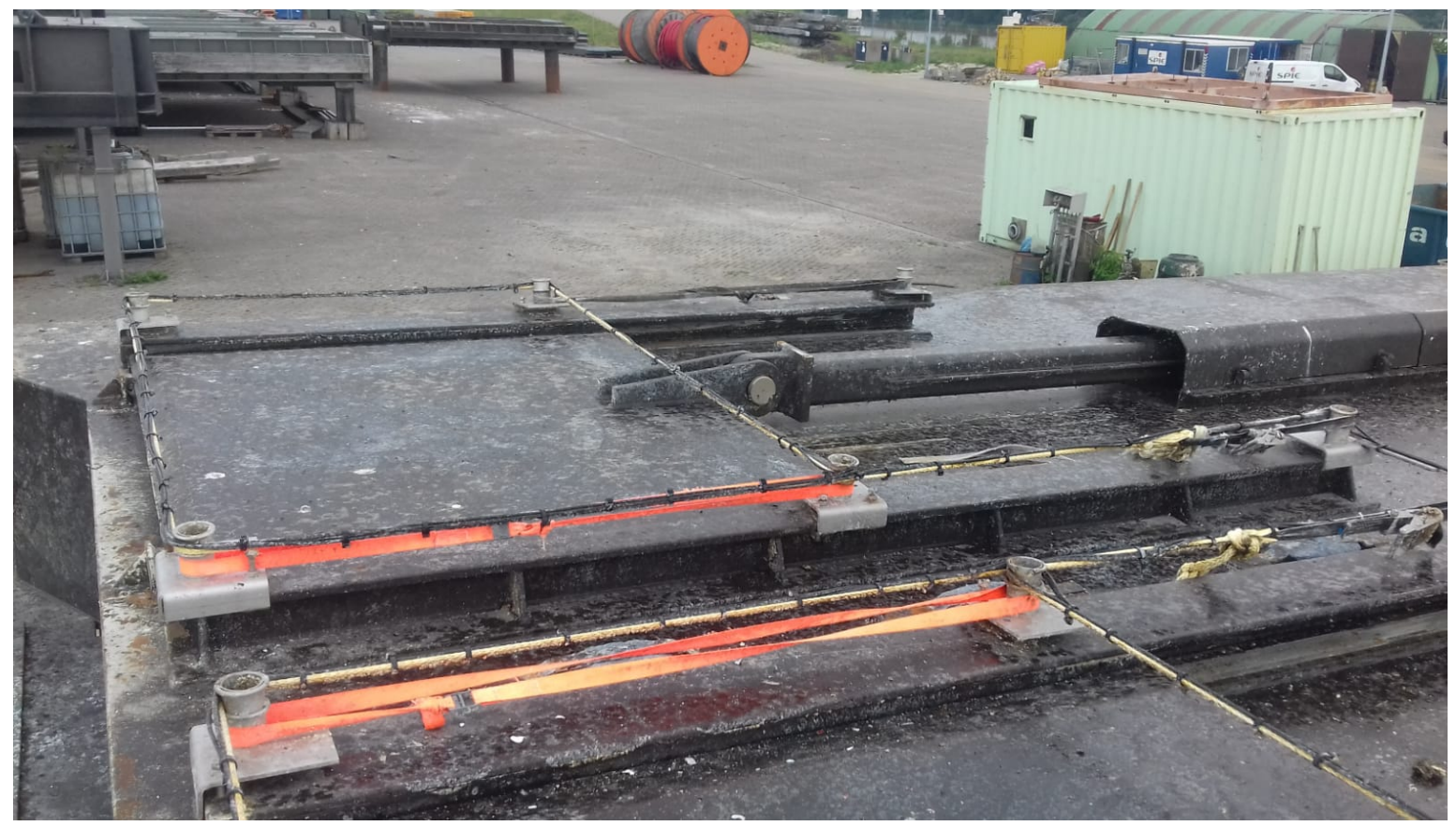


Foto 1. De detectielussen rondom de rinketten (schuifzijde) van de deuren van de Kleine Sluis te IJmuiden. Deze foto's zijn gemaakt na afloop van het project bij het opruimen (Mei 2018). De deuren zijn hier verwijderd door SPIE en op het land gelegd voor onderhoud. De lussen zijn aangebracht onderwater met behulp van duikers en na afloop op het land verwijderd toen de deuren zijn vervangen.

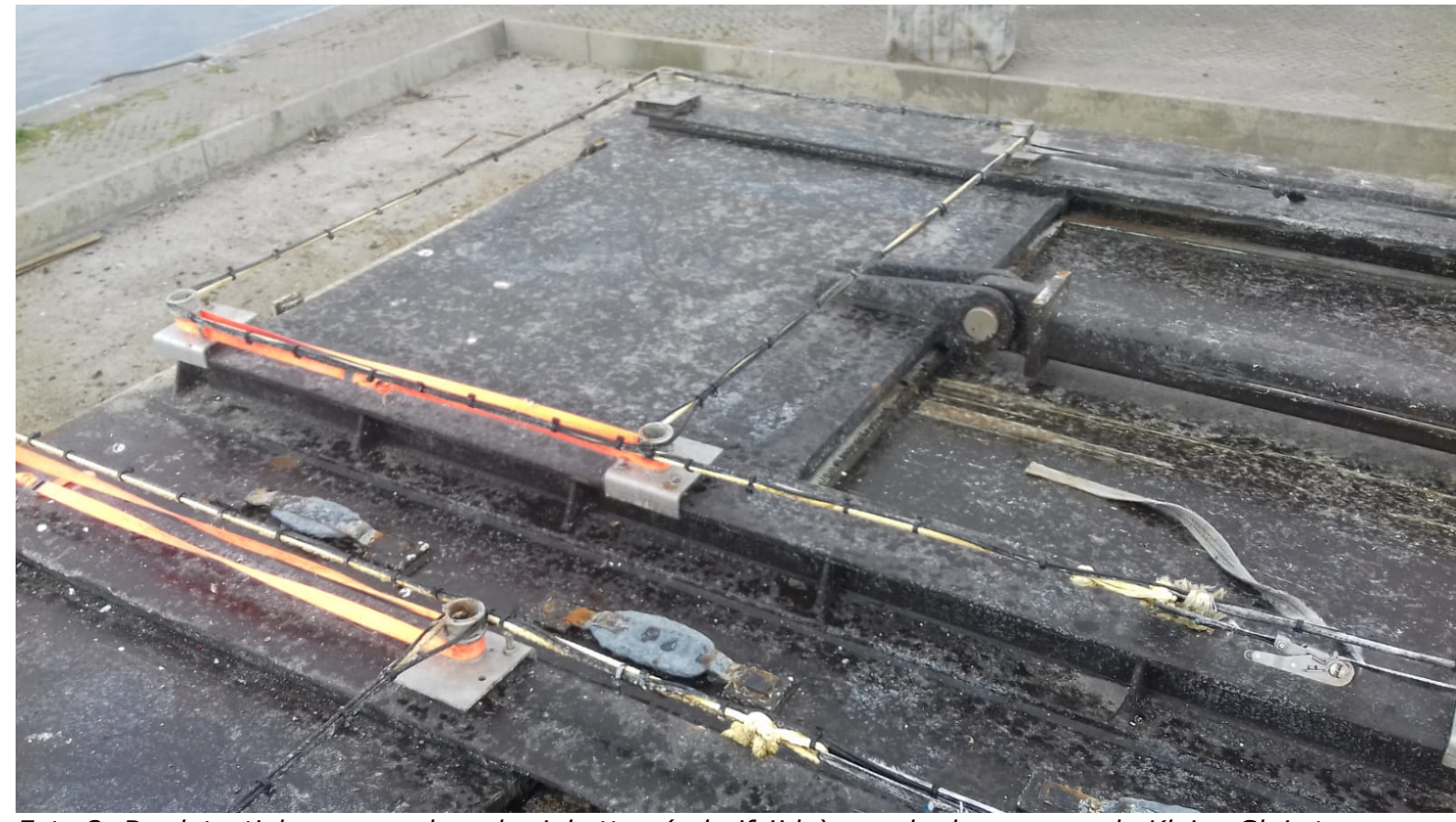

Foto 2. De detectielussen rondom de rinketten (schuifzijde) van de deuren van de Kleine Sluis te IJmuiden. Deze foto's zijn gemaakt na afloop van het project (Mei 2018). De deuren zijn hier verwijderd door SPIE en op het land gelegd voor onderhoud. De lussen zijn aangebracht onderwater met behulp van duikers en na afloop op het land verwijderd toen de deuren zijn vervangen.

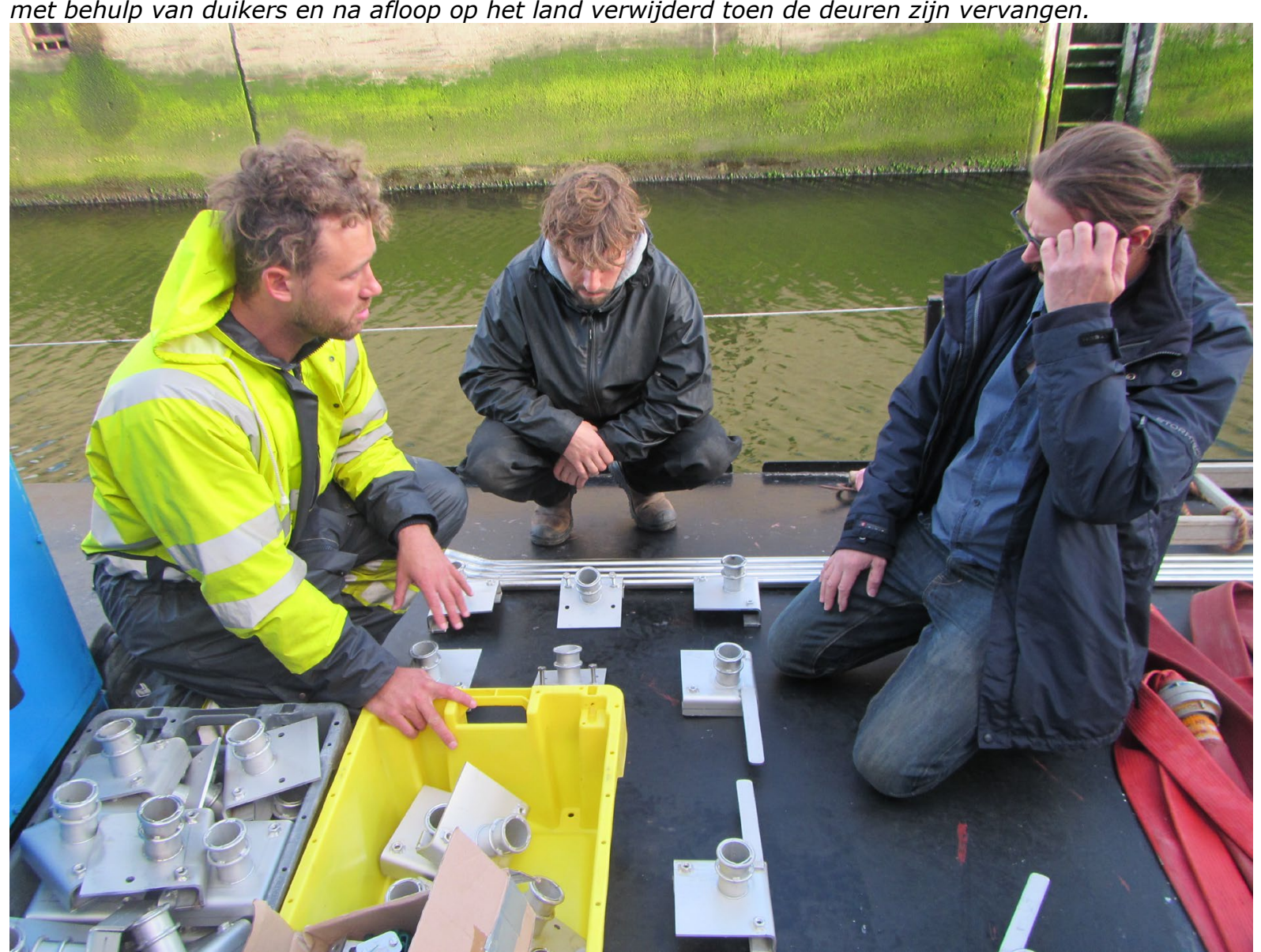

Foto 3. De constructie van de lussen wordt uitgelegd aan duikers van WALS door Dirk Burggraaf (WMR). 


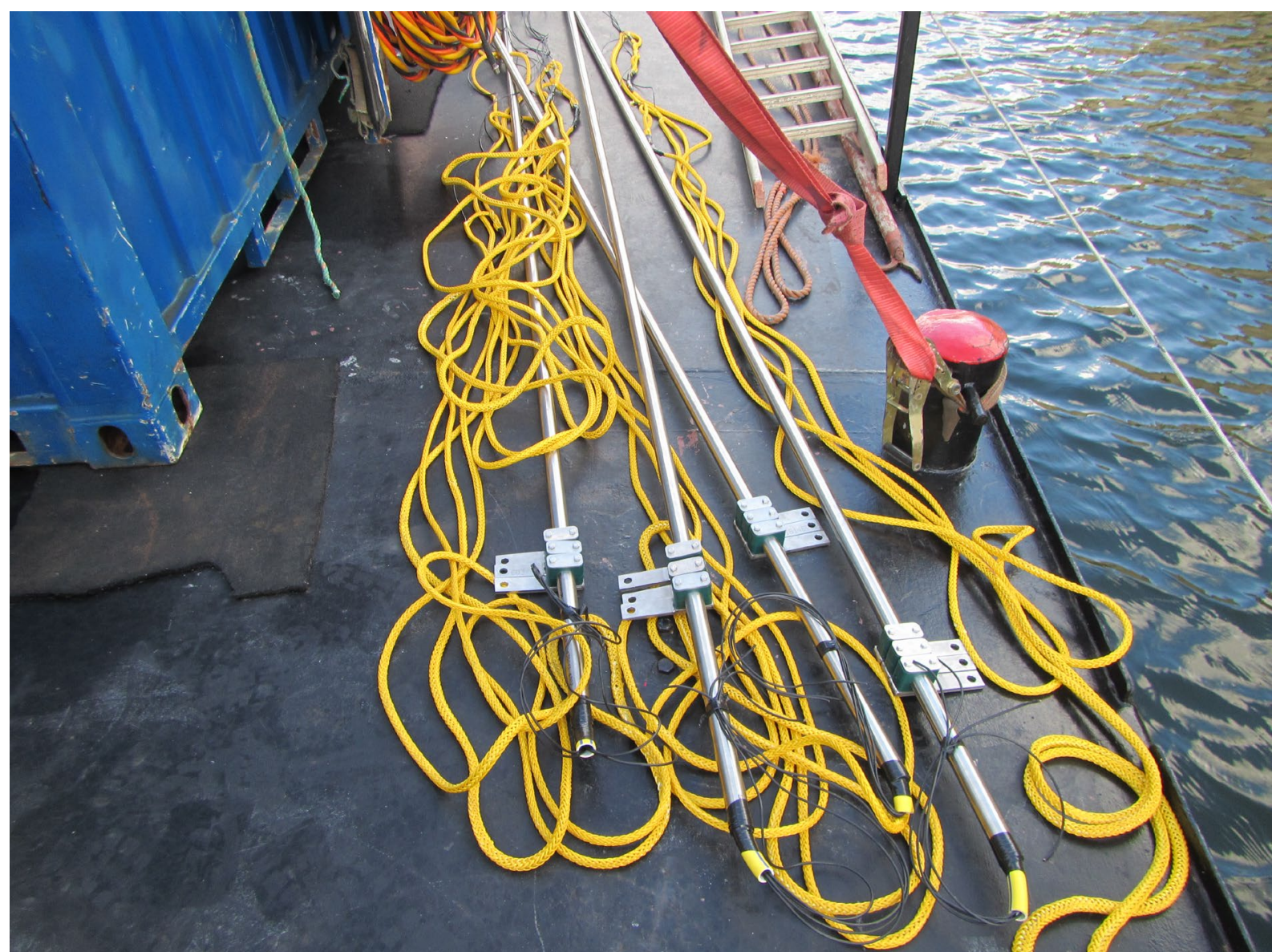

Foto 4. De DYNEEMA draden met geïntegreerde antenne kabels (enkel loops). Na testen op locatie is gebruik gemaakt van een 3 dubbele loop waarbij de DYNEEMA draad als steun voor de lus gold.

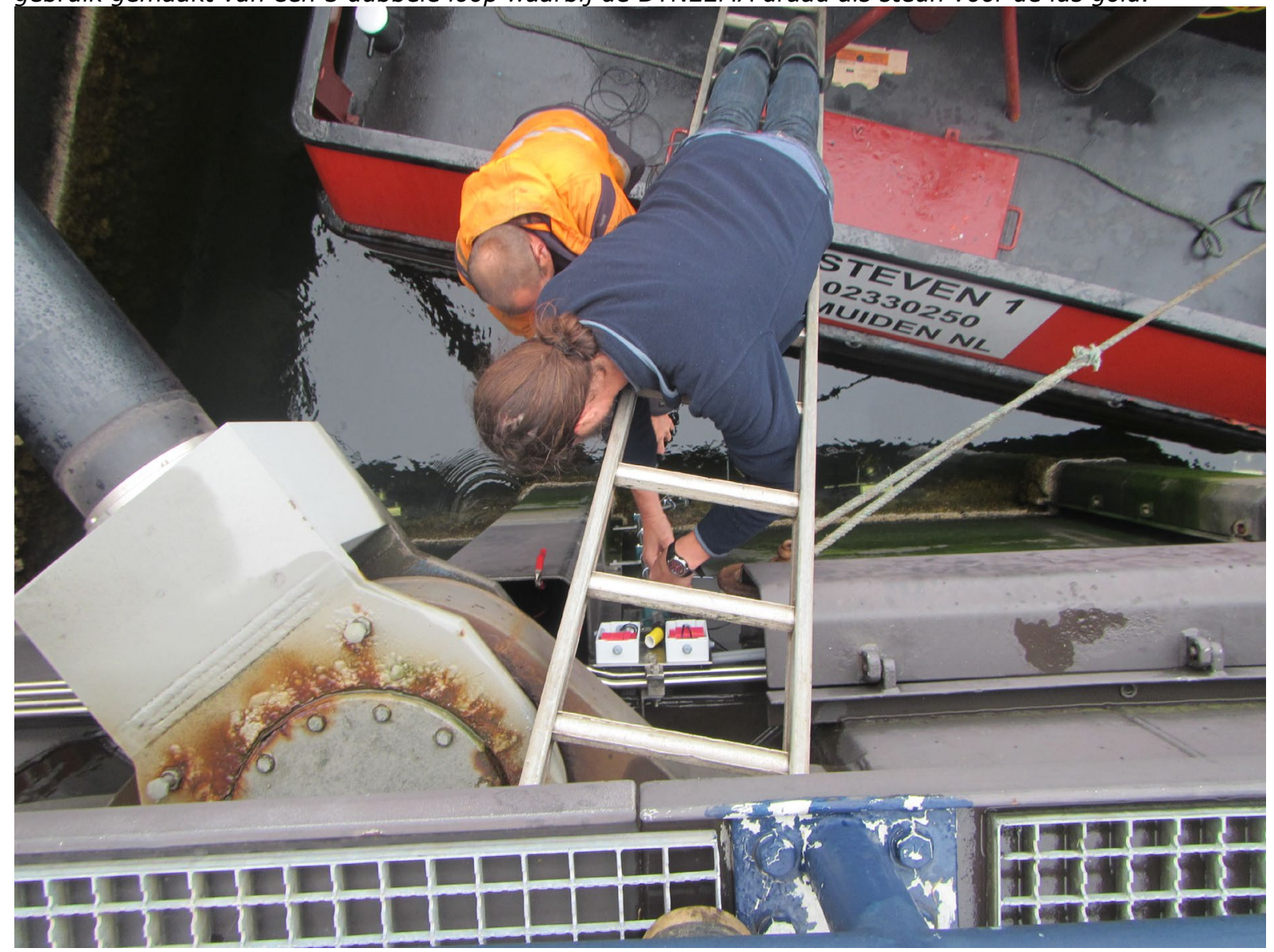

Foto 5. De plaatsing van de tuner boxen op de deur. 


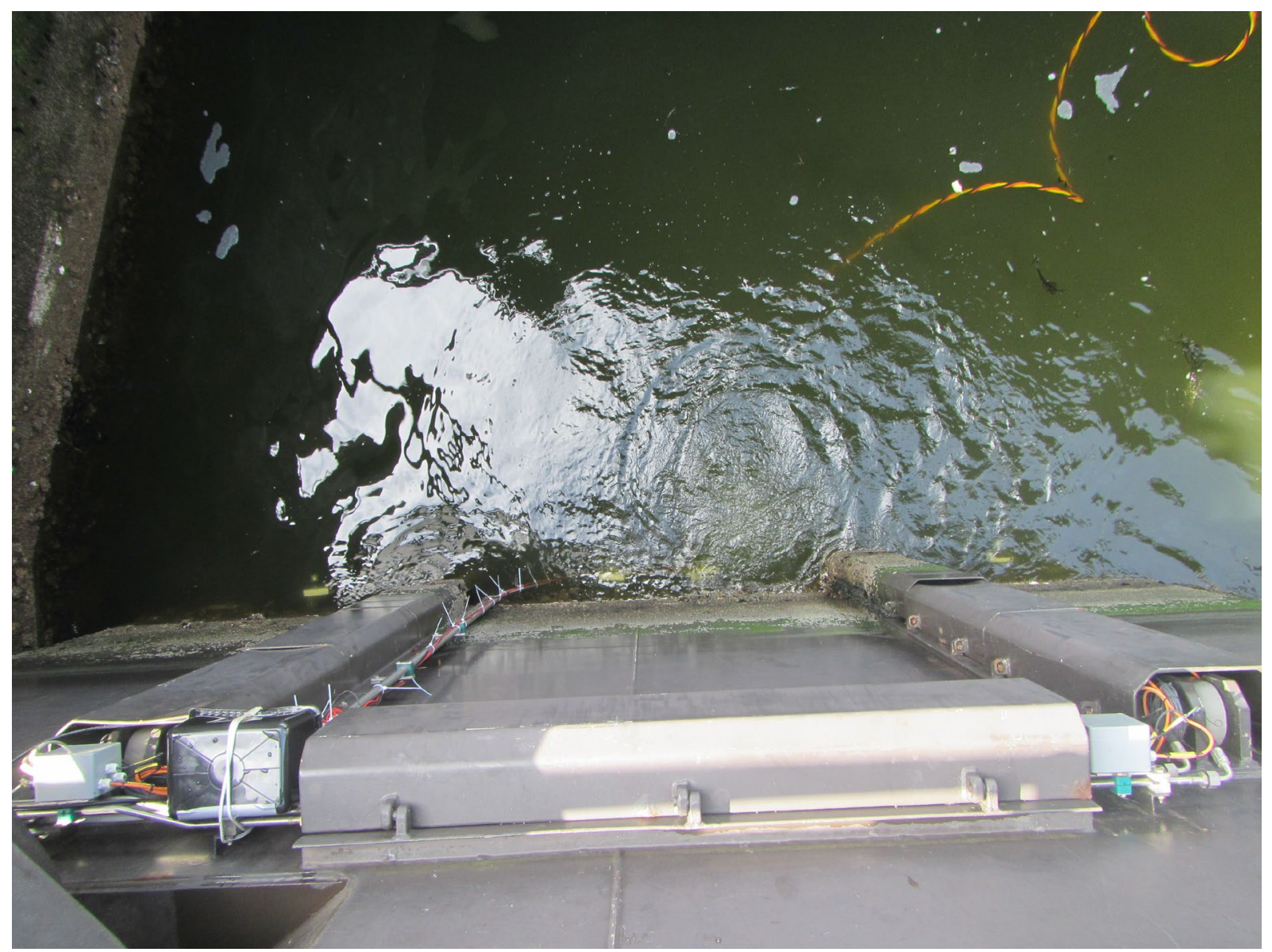

Foto 6. De plaatsing van de detectielussen onderwater door WALS diving.

Er is gebruik gemaakt van DYNEEMA draad en op maat gemaakte RVS profielen om de antenne kabels te plaatsen op de constructie rond de rinketten in de deur (foto 4). Bij het binnenhoofd is gebruik gemaakt van 3 loops van $2,5 \mathrm{~mm}^{2}$ bij het buitenhoofd is een enkele loop van $4 \mathrm{~mm}^{2}$ aan de zeezijde bevestigd. Aan het buitenhoofd was veel storing en is de drie dubbele loop van $2,5 \mathrm{~mm}^{2} \mathrm{draad}$ vervangen door een enkele $4 \mathrm{~mm}^{2}$ draad. Deze bleek in deze situatie beter te werken. De antennes zijn bevestigd aan Standard Remote Tuner Boxes welke op de deuren werden bevestigd. Per deur zijn er twee antennes geplaatst welke aan één 'Multi-Antenna HDX reader' (Oregon) werd gekoppeld. De readers waren draadloos gesynchroniseerd. Hiervoor werd de noordelijke reader aangemerkt als 'master' en de zuidelijke als 'slave'. Tijdens het testen is gebleken dat er kans is op overlap in detectie range tussen lussen op dezelfde deur, maar niet tussen de deuren.

Alle antennes zijn onderwater getest op detectierange waarbij het centrum van de lus als leidend werd genomen voor een volledige dekking van de lus. De testen zijn uitgevoerd met een geopende rinket. Alle antennes hadden een volledige dekking met een $32 \mathrm{~mm}$ tag onder deze omstandigheden.

\subsubsection{Controle systemen}

De systemen zijn gedurende het project meerdere malen op werking gecontroleerd waarbij de gegevens werden uitgelezen. Gedurende het project is de noordelijke reader aan het binnenhoofd in storing geraakt. Hierdoor is deze tussen 25 oktober en 22 november 2017 buiten werking geweest. In de tussentijd is geprobeerd door vervanging van tunerboxen en bekabeling het probleem te verhelpen. Uiteindelijk is op 22 november 2017 de reader vervangen en was het probleem verholpen. 


\section{Resultaten}

\subsection{Verdeling van migratie over het complex}

Om te bepalen welke rol de Kleine Sluis speelt bij de uittrek van schieraal ten opzichte van alle andere sluizen in het complex is er een analyse uitgevoerd op de schieralen die zijn uitgerust met een VEMCO zender. Deze verdeling is nodig om de uiteindelijke passage-efficiëntie van de vismigratievoorziening van de Kleine Sluis te bepalen.

\subsubsection{Verdeling succesvolle passage sluiscomplex}

In het kanaal zijn 50 schieralen met een akoestische transmitter uitgezet. Van deze alen zijn er 47 aan de buitenzijde van het sluiscomplex gedetecteerd, 2 alen zijn als laatste op het Noordzeekanaal zelf gezien en 1 aal is voor het laatst bij de Oranjesluizen gedetecteerd. Van de 47 succesvolle alen, zijn er 2 alen weer naar het kanaal terug gezwommen: nr. 1 eerste passage via Noordersluis naar zee en via het gemaal/spuisluis weer terug het NZK om vervolgens weer zeewaarts te zwemmen via gemaal/spuisluis. Nr. 2 heeft eerst de Noordersluis gepasseerd en is vervolgens weer via de Noordersluis terug gezwommen richting kanaal. Van de 47 eerste passages door het sluiscomplex trekken 14 exemplaren $(29,8 \%)$ via Spuisluis/Gemaal, 25 exemplaren $(53,2 \%)$ via de Noordersluis, 5 exemplaren $(10,6 \%)$ via de Middensluis en 3 exemplaren $(6,4 \%)$ via de Zuider-/Kleine Sluis (Figuur 3-1).

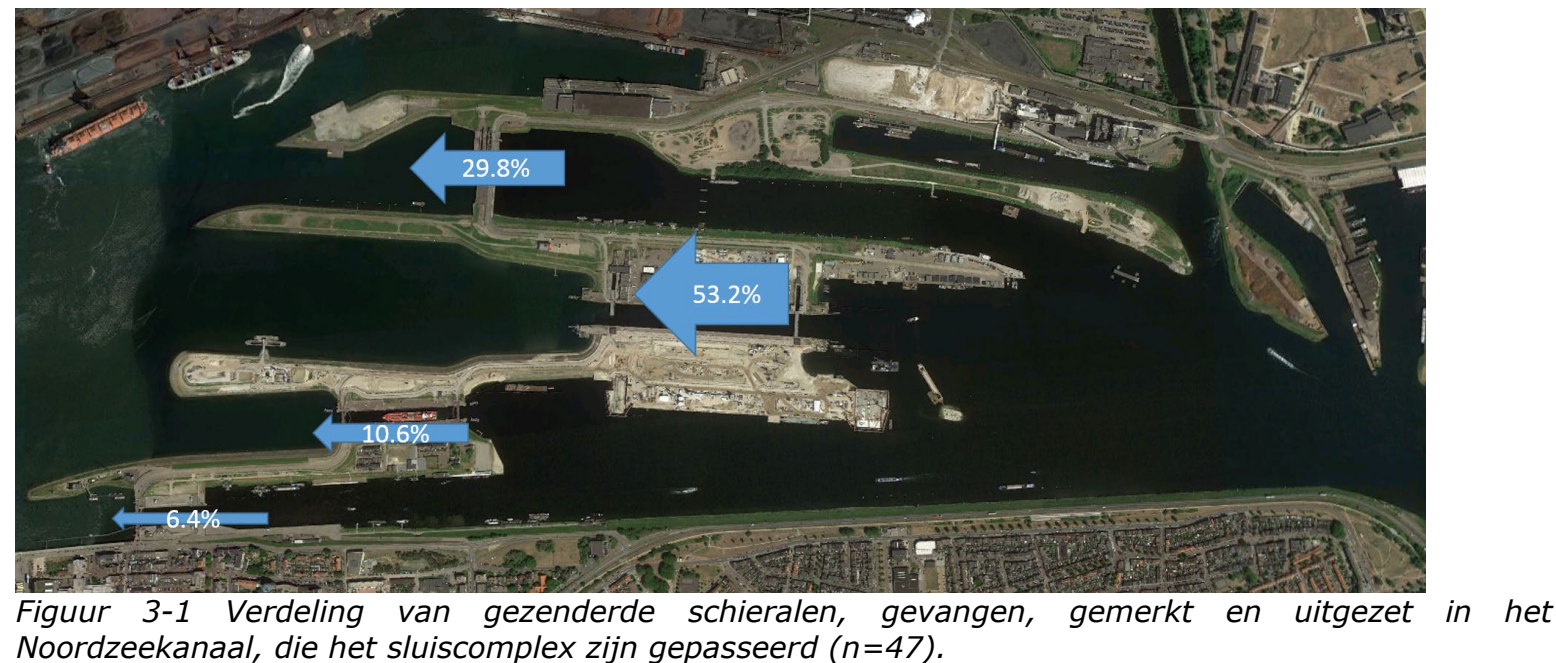

Telemetrie alen elders uitgezet

In totaal zijn er 78 schieralen met een akoestische transmitter, die elders zijn uitgezet, gedetecteerd aan de buitenzijde van het Noordzeekanaal. De verdeling over het complex is: 36 exemplaren $(46,1 \%)$ via Spuisluis/Gemaal, 28 exemplaren $(35,9 \%)$ via de Noordersluis, 10 exemplaren $(12,8 \%)$ via de Middensluis en 4 exemplaren (5,1\%) via de Zuider-/Kleine Sluis (Figuur 3-2). 


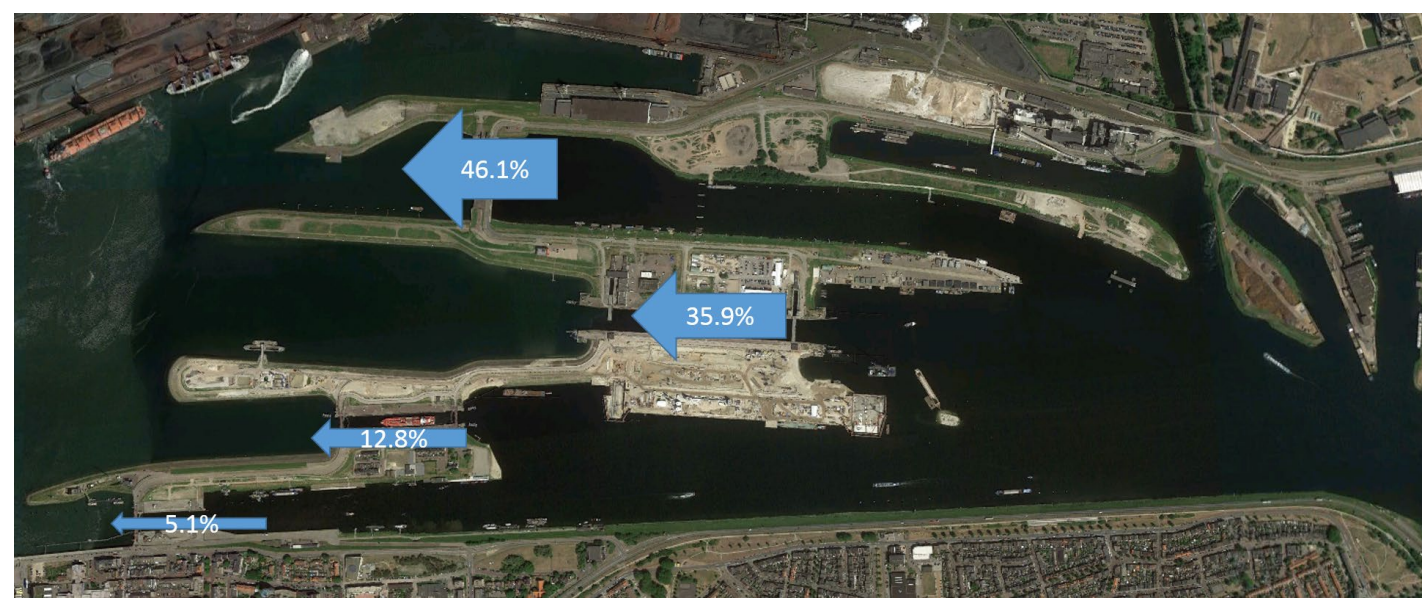

Figuur 3-2 Verdeling van gezenderde schieralen, gevangen, gemerkt en uitgezet elders in aansluitende gebieden van het Noordzeekanaal, die het sluiscomplex zijn gepasseerd $(n=78)$.

Verdeling over het complex

Als we alle 125 gepasseerde alen gezamenlijk nemen is de verdeling: 50 exemplaren $(40,0 \%)$ Spuisluis/Gemaal, 53 exemplaren (42,2\%) Noordersluis, 15 exemplaren $(12,0 \%)$ Middensluis en 7 exemplaren (5,6\%) Zuider-/Kleine Sluis (Figuur 3-3).

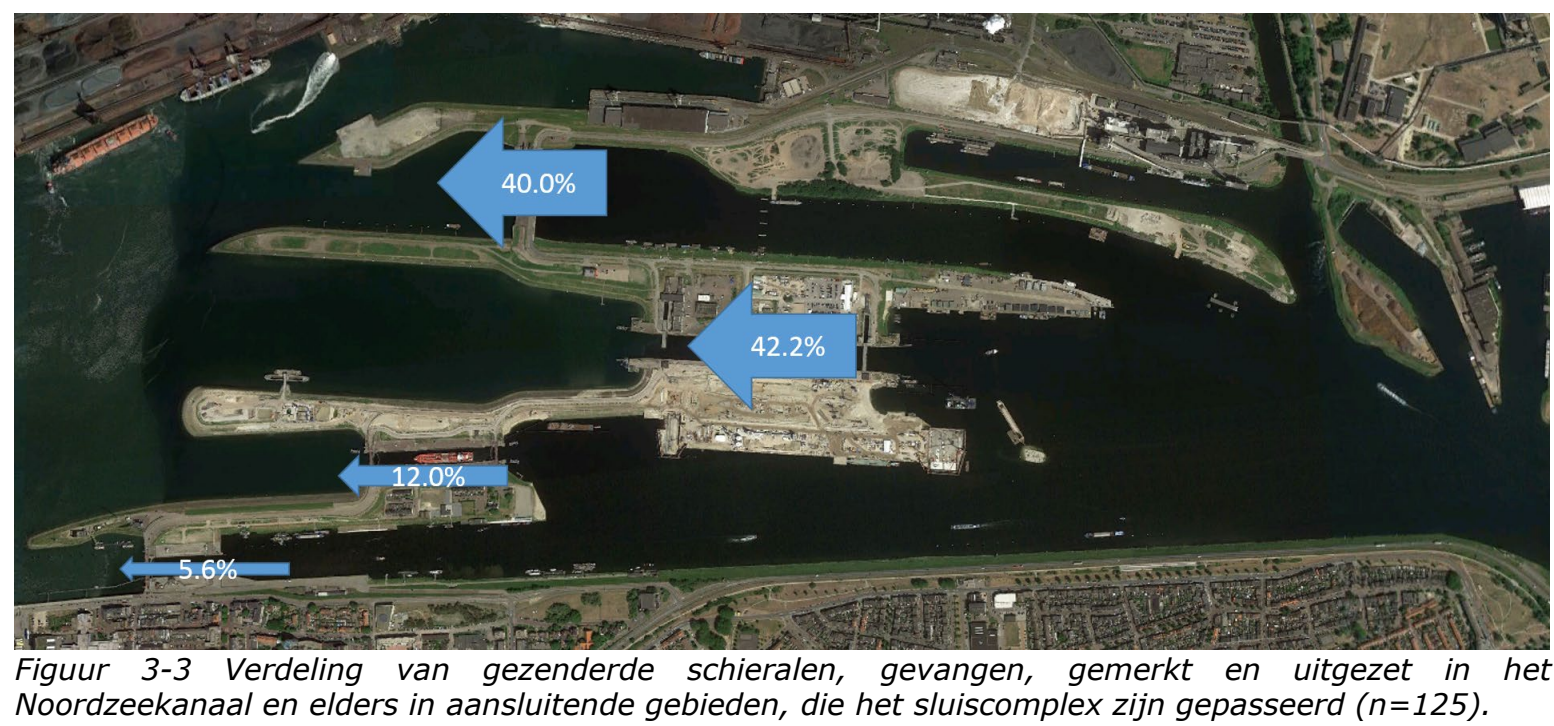

De verdeling van de debieten over de verschillende objecten in IJmuiden liep tussen de maanden oktober, november en december 2017 niet ver uiteen en was gemiddeld verdeeld volgens Tabel 4. In de donkere uren, globaal tussen 17:00 uur en 8:00 uur, worden de Zuider- en de Kleine Sluis relatief minder gebruikt en blijven de andere debieten, inclusief de vismigratievoorziening, gemiddeld op peil. In de periode oktober-dec 2017 heeft het gemaal relatief veel gedraaid en verzorgde $58 \%$ van het uitgaande debiet, het spuicomplex slechts $14 \%$ (Tabel 4 ).

Tabel 4 Verdeling zee- en kanaalwaartse debieten te IJmuiden in de periode oktober-december 2017, totaal en tijdens de donkere uren

\begin{tabular}{|c|c|c|c|c|c|c|c|c|}
\hline Totaal & gemaal & spui & N'sluis & M'sluis & Z'sluis & K'sluis (schut) & K'sluis (visp.) & Totaal \\
\hline Zeewaarts (m3/s) & 89 & 22 & 35 & 5,030 & 2,401 & 0,153 & 0,479 & 153 \\
\hline Zeewaarts (\%) & $58 \%$ & $14 \%$ & $23 \%$ & $3,28 \%$ & $1,57 \%$ & $0,10 \%$ & $0,31 \%$ & $100 \%$ \\
\hline Kanaalwaarts (m3/s) & - & - & -36 & $-5,248$ & $-2,528$ & $-0,171$ & $-6,291$ & -50 \\
\hline Kanaalwaarts (\%) & $0 \%$ & $0 \%$ & $72 \%$ & $10,49 \%$ & $5,05 \%$ & $0,34 \%$ & $12,58 \%$ & $100 \%$ \\
\hline
\end{tabular}

\begin{tabular}{|l|r|r|r|r|r|r|r|r|r|}
\hline \multicolumn{1}{|c}{ Tijdens 't donker } & \multicolumn{2}{c}{ gemaal } & \multicolumn{2}{c}{ spui } & \multicolumn{2}{c|}{ N'sluis } & \multicolumn{2}{c|}{ M'sluis } & \multicolumn{2}{c|}{ K'sluis (schut) } \\
\hline Zeewaarts (m3/sluis (visp.) & Totaal \\
\hline Zeewaarts (\%) & 90 & 21 & 34 & 4,673 & 1,662 & 0,058 & 0,509 & 152 \\
\hline Kanaalwaarts (m3/s) & $59 \%$ & $14 \%$ & $22 \%$ & $3,07 \%$ & $1,09 \%$ & $0,04 \%$ & $0,33 \%$ & $100 \%$ \\
\hline Kanaalwaarts (\%) & - & - & -35 & $-4,877$ & $-1,750$ & $-0,065$ & $-6,725$ & -48 \\
\hline
\end{tabular}


Bij de berekening van het uitwisselingsdebiet via enkel de schutsluizen is uitgegaan van een volledige wateruitwisseling onder invloed van het dichtheidsverschil (Tabel 5). De passage van schieraal per sluis $(n=75)$ is ook weergegeven in de tabel (Tabel 5 ). De correctie voor de kolkbezetting was voor de Noorder- en de Middensluis 8\% en voor de Zuider- en de Kleine sluis 6\% (Arcadis 2014). Na de uiteenzetting van getallen lijkt er een relatie tussen het debiet en de uiteindelijke verdeling van schieraal bij de uittrek richting zee. De verdeling van de schieralen over de schutsluizen volgt ongeveer de debietverdeling daartussen, beter dan de verdeling over het aantal schuttingen (Tabel 5).

Tabel 5 Verdeling zeewaartse debieten, schuttingen en passage schieralen over zeesluizen IJmuiden tijdens de donkere uren in de periode oktober-december 2017 (schieraalpassage $n=75$ ).

\begin{tabular}{|c|c|c|c|c|c|}
\hline Tijdens 't donker & N'sluis & M'sluis & Z'sluis & K'sluis (schut) & Totaal \\
\hline Zeewaarts debiet (\%) & $83 \%$ & $11 \%$ & $4,0 \%$ & $1,4 \%$ & $100 \%$ \\
\hline Schuttingen & 629 & 482 & 581 & 72 & 1.691 \\
\hline Schuttingen/nacht & 6,8 & 5,2 & 6,3 & 0,8 & 18,4 \\
\hline Schuttingen (\%) & $37 \%$ & $29 \%$ & $34 \%$ & $4,3 \%$ & $100 \%$ \\
\hline Schieraalpassage (\%) & $71 \%$ & $20 \%$ & \multicolumn{2}{|c|}{$9 \%$} & $100 \%$ \\
\hline
\end{tabular}

\subsubsection{Attractie van Zuidersluis en Kleine Sluis op aal}

In totaal zijn er 128 schieralen gedetecteerd bij het sluiscomplex, waarvan er 125 stuks succesvol zijn gepasseerd. Van al deze schieralen zijn er 37 gedetecteerd door de receiver bij de Zuider-/Kleine Sluis. Hiervan zijn er twee afkomstig van het Noordzeekanaal, omgekeerd en daarna niet meer gedetecteerd. 28 schieralen zijn elders het sluiscomplex gepasseerd en 7 alen passeerden de Zuider/Kleine Sluis (5,6\% van 125). Van de 35 schieralen die bij de Zuider-/Kleine Sluis zijn gezien én deze sluizen zijn gepasseerd (alen met migratiedrang) is het passagesucces via de Zuider-/Kleine Sluis $20.0 \%$ (7 op 35). Indien de twee alen om andere redenen dan het ontbreken van migratiedrang zijn omgekeerd en niet meer gedetecteerd (predatie, andere route, etc), is het passage succes 18,9\% ( 7 op 37).

\subsection{Detecties Kleine Sluis}

Naast verdeling van uittrekkende schieraal over het gehele complex en specifiek de attractie van schieraal op de Kleine Sluis, is er ook een detail analyse uitgevoerd van de schieralen die zijn gedetecteerd bij de vismigratievoorziening. Deze analyse is noodzakelijk om de passage-effectiviteit te bepalen.

\section{Aantal gedetecteerde alen}

In totaal zijn er 26 schieralen gedetecteerd op één van de PIT-tag stations in de Kleine Sluis. Dit waren allemaal alen die in het NZK zijn gevangen, gemerkt en uitgezet. Hieronder waren geen alen die ook van een VEMCO-zender waren voorzien. Dit is $1,3 \%$ van de uitgezette schieralen die gemerkt zijn op het Noordzeekanaal $(n=1975)$. Van de 26 schieralen zijn er 15 alleen bij het binnenhoofd (NZK zijde) gedetecteerd en 1 schieraal alleen bij het buitenhoofd (zeezijde). 10 schieralen zijn aan beide zijden gedetecteerd.

\section{Aantal detecties per locatie en vismigratievoorziening-stand}

Om een indruk te krijgen hoeveel schieralen er tijdens welke stand van de rinketten zijn gepasseerd zijn de detecties verdeeld over de rinketparen per deur en de fase waarin de vismigratievoorziening regeling zich bevind (Tabel 6). Indien een aal verschillende malen is gedetecteerd (op een ander tijdstip) is dat een andere waarneming. Een serie aaneengeschakelde waarneming is samengenomen (vaak binnen dezelfde minuut). Tabel 7 geeft de verdeling van de fasen van de vismigratievoorziening regeling tijdens de donkere uren voor de periode oktober-december 2017 (zie ook Tabel 2a).

Bij het binnenhoofd zijn de meeste detecties geweest tijdens de HW1-fase (89\%). In deze fase is de meeste zuidelijke schuif $100 \%$ open en de overige drie zijn gesloten. De meeste alen zijn dan ook gedetecteerd aan de zuidzijde. Het lage aantal detecties tijdens de HW2-fase is te verwachten, aangezien dan alle rinketten in de binnendeuren gesloten zijn. Dat het aantal detecties tijdens de LW- 
fase ook zo laag is is tegen de verwachting, aangezien dan de rinketten aan binnen- en buitenhoofd allemaal voor de helft open staan en er een zeewaartse stroming door de kolk plaatsvindt. De schieralen kunnen zich dan in principe met de stroming laten meevoeren. Volgens de dataregistratie is de frequentie waarop fase LW optreedt slechts $8 \%$, waarvan maar iets meer dan de helft van de tijd de stroming richting zee is.

Aan het buitenhoofd zijn er relatief meer detecties tijdens de HW2-fase (58\%). Tijdens deze fase zijn alle schuiven aan die zijde $100 \%$ open. De stroomsnelheid richting kanaal tijdens die fase zal veelal te hoog zijn voor een geslaagde passage naar zee (25-percentiel is 2,56 m/s, Tabel 2a). Tijdens de HW1fase, de meest zuidelijke rinket $10 \%$ open, is het aantal detecties $17 \%$. Passage via de rinket naar zee zal dan (waarschijnlijk) niet mogelijk zijn geweest gezien de hoge stroomsnelheden (Tabel 2a). Ook aan het buitenhoofd is het aantal detecties tijdens de LW-fase laag: $8 \%$.

De detecties tijdens de momenten dat de vismigratievoorziening niet in werking is, aan beide zijden 2 stuks, kunnen hebben plaatsgevonden tijdens een schutting, waarbij de rinketten worden geopend bij het nivelleren. Maar het kunnen ook detecties zijn naast de rinketten binnen het bereik van de antennes.

Tabel 6 Aantal keer dat een gemerkte schieraal $(n=26)$ is gedetecteerd ten tijde van de diverse fasen van de vismigratievoorziening. Een serie van detecties is hierbij samengenomen tot één detectie.

\begin{tabular}{|c|c|c|c|c|c|c|c|c|}
\hline & \multicolumn{4}{|c|}{ Buitenhoofd (zee) } & \multicolumn{4}{|c|}{ Binnenhoofd (NZK) } \\
\hline & noord & zuid & totaal & $\%$ & noord & zuid & totaal & $\%$ \\
\hline niet in functie & - & 2 & 2 & $17 \%$ & - & 2 & 2 & $4 \%$ \\
\hline LW & - & 1 & 1 & $8 \%$ & - & 2 & 2 & $4 \%$ \\
\hline HW1 & - & 2 & 2 & $17 \%$ & 2 & 45 & 47 & $89 \%$ \\
\hline HW2 & 5 & 2 & 7 & $58 \%$ & - & 2 & 2 & $4 \%$ \\
\hline
\end{tabular}

Tabel 7 Verdeling van de fasen van de vismigratievoorziening tijdens de donkere uren voor de periode oktober-december 2017.

\begin{tabular}{|c|c|c|c|c|}
\hline & okt & nov & dec & gem. \\
\hline niet in functie & $10 \%$ & $12 \%$ & $28 \%$ & $17 \%$ \\
\hline LW & $12 \%$ & $8 \%$ & $8 \%$ & $9 \%$ \\
\hline HW1 & $55 \%$ & $55 \%$ & $41 \%$ & $50 \%$ \\
\hline HW2 & $23 \%$ & $26 \%$ & $23 \%$ & $24 \%$ \\
\hline
\end{tabular}

Detecties per schieraal

Per schieraal is een schematische weergave gemaakt van de detecties tijdens het experiment (Figuur 3-4). De meeste schieralen zijn aan de zuidzijde van het binnenhoofd gedetecteerd. Gezien de hoge stroomsnelheden door de geopende rinket aan het binnenhoofd tijdens HW1 (25-percentiel 1,84 m/s, Tabel 2a) kunnen dit detectie zijn van alen die vergeefs trachten te passeren, maar wel binnen het bereik van de antenne komen. De herhaalde detecties bij hetzelfde rinket zijn hiervoor een aanwijzing en het bij veel exemplaren ontbreken van detecties aan de andere zijde van de kolk. Twee schieralen zijn (ook) overdag gedetecteerd, nr. 18 en 21, alle overige detecties tussen zonsondergang en opgang.

Alleen aan de binnenhoofd gedetecteerd

In totaal zijn 15 schieralen (nr. 3, 4, 5, 6, 7, 8, 9, 10, 11, 13, 14, 19, 21, 25 en 26) alleen aan de kanaalzijde gedetecteerd. Alle, behalve nr. 5, zijn gedetecteerd tijdens HW1. De tweede detectie van nr. 5 vond plaats terwijl de vismigratievoorziening niet actief was, dus vermoedelijk tijdens een schutting, waarbij de rinketten aan het binnenhoofd zijn gebruikt om te nivelleren (zeepeil stond ca. $1,9 \mathrm{~m}$ hoger dan kanaalpeil).

\section{Eerst aan de buitenzijde gedetecteerd}

Er zijn 4 schieralen (nr. 2, 15, 17 en 22), die eerst aan de zeezijde (buitenhoofd) zijn gedetecteerd. Deze kunnen afkomstig zijn van de Buitenhaven, maar en dat is meer aannemelijk, ze kunnen ook de kolk vanaf het kanaal in zijn gezwommen tijdens een schutting. 
Vastgestelde verblijftijd in de sluis

Van schieraal nr. 1, 12, 16, 18, 20, 23 en 24 kan iets worden vermeld over de verblijftijd doordat er eerst aan de kanaalzijde en vervolgens aan de zeezijde een detectie is geweest.

- Schieraal nr. 1 is de sluis ingezwommen tijdens HW 1 en is de schuif bij de zeezijde gepasseerd tijdens HW 2. De tijd tussen de eerste en laatste detectie is 4 uur en 18 minuten en tussen de laatste detectie aan de kanaalzijde en de detectie aan de zeezijde 2 uur en 24 minuten;

- Schieraal nr. 12 is de kolk binnengezwommen tijdens HW1 en 1 uur en 28 minuten later voor het laatst gedetecteerd aan de zeezijde tijdens HW2;

- Schieraal nr. 16 is de kolk mogelijk met een schutting ingezwommen en tijdens fase LW aan het buitenhoofd gedetecteerd (tijdens zeewarts debiet). Tussen deze detecties zat 2 uur en 19 minuten. Deze aal is 42 minuten later nog eens aan het buitenhoofd gedetecteerd;

- Schieraal nr. 18 is tijdens HW1 de sluis in gezwommen en ca. 10 uur later aan de zeezijde gedetecteerd tijdens HW1. Daar zal de aal niet kunnen zijn gepasseerd, aangezien er in deze fase een rinket op een kier staat aan het buitenhoofd met een hele hoge kanaalwaartse stroming. Wellicht dat de aal al op een ander moment tijdens een schutting aan de zeezijde van de kolk was beland;

- Schieraal nr. 20 is tijdens HW1 aan de kanaalzijde gedecteerd en 2 uur en 6 minuten later tijdens HW2 aan de zeezijde;

- Schieraal nr. 23 is tijdens HW1 aan de kanaalzijde gedetecteerd en 1 uur en 11 minuten later gedetecteerd aan de zeezijde tijdens HW2;

- Schieraal 24 is tijdens HW1 aan de kanaalzijde 2x gedetecteerd met ruim een uur tussenpoze. De volgende detectie was ruim twee dagen later aan de zeezijde tijdens HW2. Dit zou betekenen dat de aal al die tijd in de kolk verbleef, of tussentijds met een schutting de kolk heeft verlaten. 


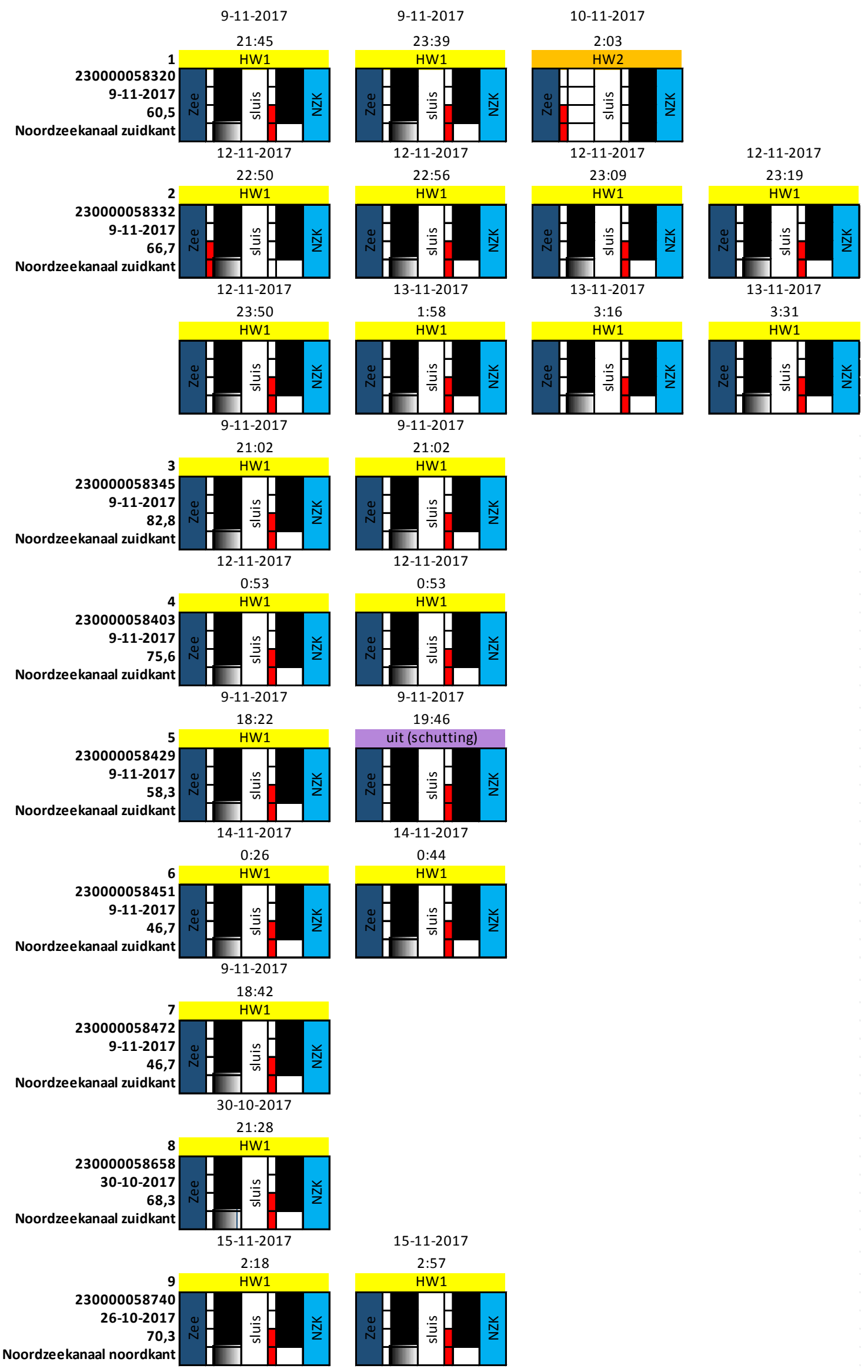

Figuur 3-4 Detecties per schieraal ( $\mathrm{nr}$, PITnr. zenderdatum, lengte (cm), uitzetlocatie). In de figuur wordt per detectie (aaneengeschakelde serie) weergegeven de datum, tijd en fase van de vismigratievoorziening. Weergegeven is een schematisch bovenaanzicht. De sluisdeuren zijn zwart (dicht), gearceerd (10\% of $50 \%$ open of wit (geheel open). De rode vlakken stelt de locatie van detectie voor. Rechts kanaalzijde, links zeezijde. 


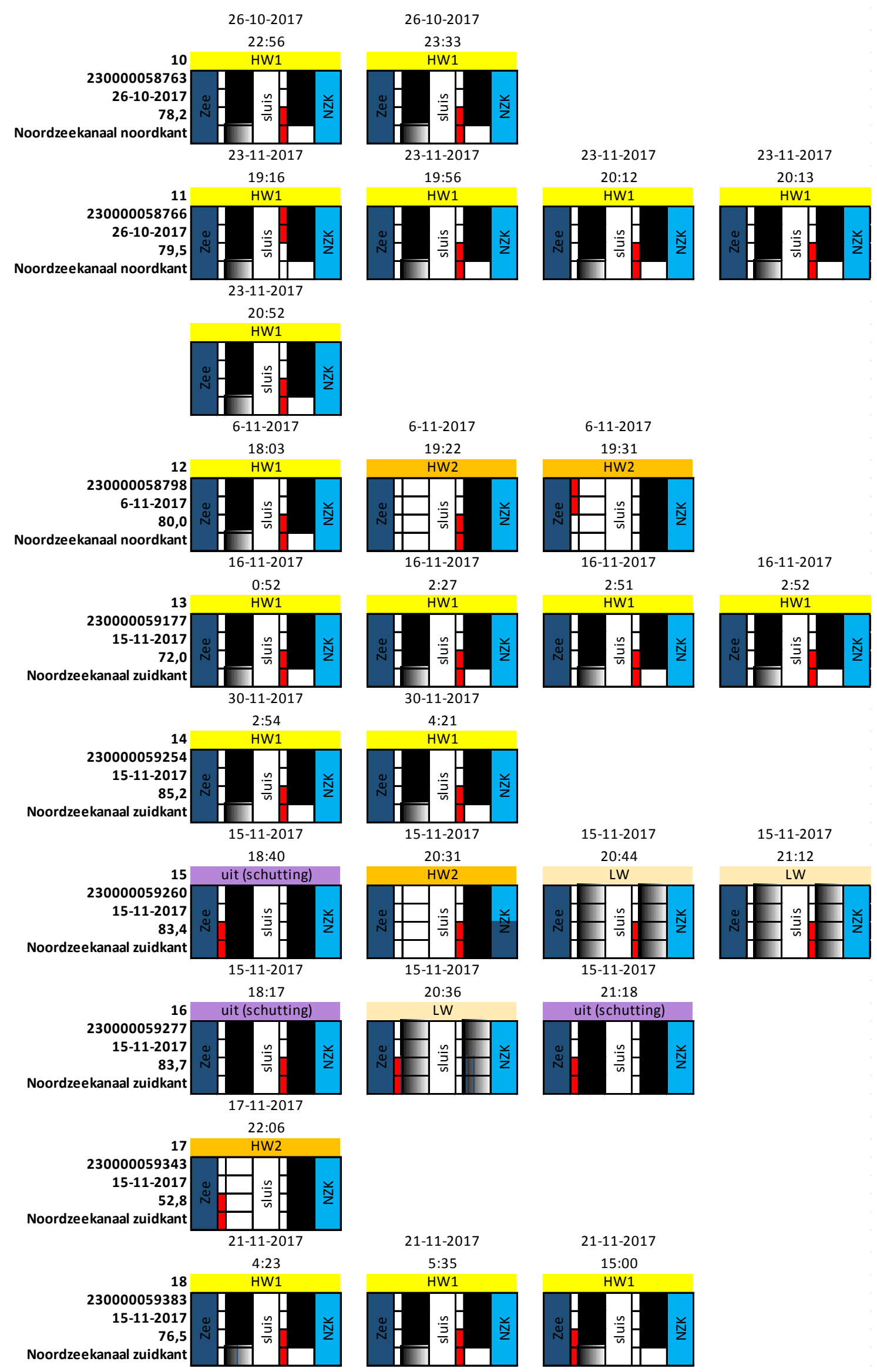

Figuur 3-4, vervolg (2 van 3) 


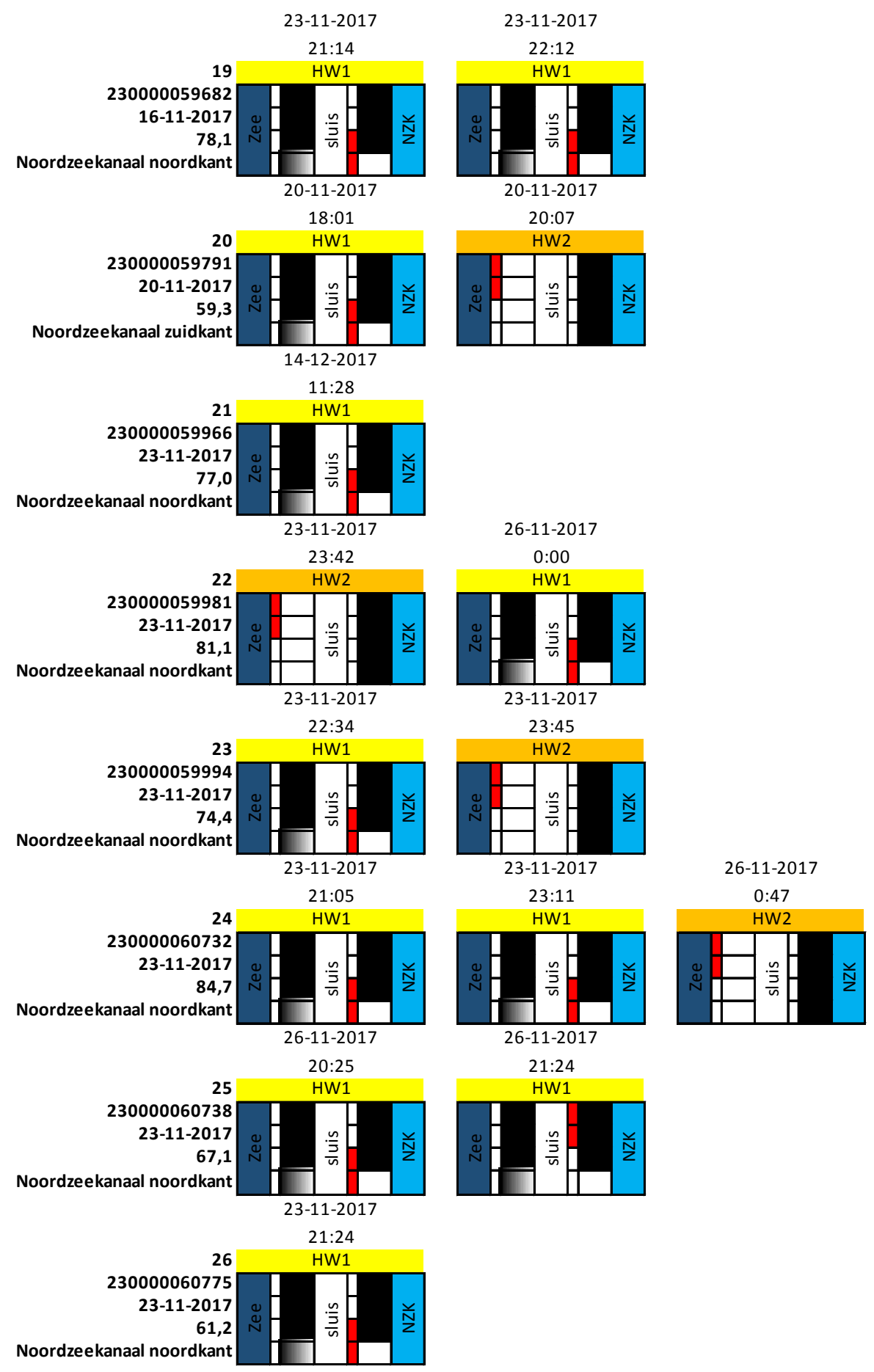

Figuur 3-4, vervolg (3 van 3) 


\section{Discussie en Conclusie}

Detecties, timing en verblijftijd

Van de 1975 schieralen met een tag zijn 26 schieralen gedetecteerd nabij de schuiven van de deuren (1,3\%). Van deze 26 schieralen zijn er waarschijnlijk 6 die de kolk zijn gepasseerd (aalnr. 1, 12, 18, 20, 23 en 24), gebruikmakend van de vismigratievoorziening. Deze zijn zowel bij het benedenhoofd als het bovenhoofd van de sluis in achtereenvolgende detecties waargenomen (Figuur 3-4). De andere 20 gedetecteerde schieralen zijn geen zekere passanten, omdat ze slechts aan de kanaalzijde zijn gedetecteerd of van buiten naar binnen zijn gezwommen. Schieraal bereikten de sluis via de vismigratievoorziening vooral tijdens HW1, wanneer de schuiven aan het binnenhoofd voor $100 \%$ open stonden. Het uitzwemmen van de kolk was veelal tijdens $\mathrm{HW} 2$, als alle rinketten aan de zeezijde open stonden en eenmaal tijdens LW. Van de schieralen waarvan de verblijftijd in de sluis kon worden vastgesteld $(n=5)$ varieerde dit van 1 uur en 11 minuten tot 2 uur en 24 minuten.

\section{Schatting van effectiviteit vismigratievoorziening.}

De verdeling van de uittrek van schieralen over het gehele complex is bepaald aan de hand van de akoestische telemetrie. 5,6\% van de dieren die succesvol de zeesluizen/spui/gemaal zijn gepasseerd hebben dit gedaan bij de Zuider-/Kleine Sluis. Hiervan zal een deel via de Kleine Sluis en een deel via de Zuidersluis zijn gepasseerd.

Het is goed mogelijk dat het debiet over de verschillende sluizen in het complex in eerste instantie de verdeling bepaalt van arriverende alen, maar de uiteindelijke verdeling van uittrekkende schieralen over de uittrekroutes wordt bepaald door de passeerbaarheid van de objecten. De verdeling van de schieralen over de schutsluizen volgt ongeveer de debietverdeling daartussen, beter dan de verdeling over het aantal schuttingen (Tabel 5).

Als wordt aangenomen dat de verdeling van schieralen over het complex volgt uit de verdeling van de zeewaartse debieten, dan zal grofweg driekwart van de 5,6\% via de Zuidersluis zijn getrokken en de rest via de Kleine Sluis, incl. vismigratievoorziening (Tabel 8). Met deze cijfers kan worden geschat hoeveel alen voorzien van een PIT-tag zullen zijn gepasseerd via de combinatie Zuider- en Kleine Sluis en hoeveel gebruik zullen hebben gemaakt van de Kleine Sluis. Er wordt aangenomen dat van de 1975 alen voorzien van een PIT-tag, 98\% succesvol is gepasseerd. Er zijn immers 125 van de 128 schieralen van een VEMCO zender succesvol gepasseerd (98\%). 98\% van 1975 komt overeen met 1935 exemplaren en 5,6\% hiervan is 108 exemplaren. Via de Kleine Sluis zouden dan 27 alen zijn gepasseerd (1/4 deel).

Tabel 8 Verdeling zee- en kanaalwaartse debieten en schuttingen tussen Zuider- en Kleine Sluis IJmuiden tussen zonsondergang en -opgang in de periode oktober-december 2017

\begin{tabular}{|c|c|c|c|c|}
\hline Tijdens 't donker & Z'sluis & K'sluis (schut) & K'sluis (visp.) & Totaal \\
\hline Zeewaarts (m3/s) & 1,662 & 0,058 & 0,509 & 2,229 \\
\hline Zeewaarts (\%) & $74,6 \%$ & $2,6 \%$ & $22,8 \%$ & $100 \%$ \\
\hline Kanaalwaarts $(\mathrm{m} 3 / \mathrm{s})$ & $-1,750$ & $-0,065$ & $-6,725$ & $-8,540$ \\
\hline Kanaalwaarts (\%) & $20,5 \%$ & $0,8 \%$ & $78,7 \%$ & $100 \%$ \\
\hline Schuttingen & 581 & 72 & & 653 \\
\hline Schuttingen (\%) & $89 \%$ & $11 \%$ & & $100 \%$ \\
\hline
\end{tabular}

Een verwacht aantal van 27 schieralen is in overeenstemming met het aantal van 26 exemplaren dat zich heeft aangediend bij de rinketten van de sluisdeuren van de Kleine Sluis. Er zullen echter ook enkele alen zijn gepasseerd tijdens een schutting, zonder te zijn gedetecteerd. Het aantal nachtelijke schuttingen met de kleine sluis was echter minder dan 1 per nacht (Tabel 5). Naast het grote zeewaartse debiet zal ook de forse instroom van zeewater via de vismigratievoorziening (ca. 13\% van alle instroom via de zeesluizen (Tabel 4) een aantrekkende werking hebben gehad, wat de uittrekverhouding tussen Kleine Sluis en Zuidersluis positief kan hebben beïnvloed en zelfs kan hebben gezorgd voor enige extra aantrekking ten opzichte van de naastgelegen Middensluis. 
Aan de aanbodkant moeten we rekening houden met de fractie alen die na een aanvankelijke aankomst bij de Zuider-/Kleine Sluis omkeert en via een andere route zijn/haar weg naar zee vindt. Dit aandeel is vastgesteld op $80 \%$ zogenoemde omkeerders en $20 \%$ succesvolle passanten (7 op 35 schieralen). Als we corrigeren voor dit aandeel (108 schieralen $=20 \%$ ), dan moeten we rekenen met in totaal 555 schieralen die zich aandienen bij de Zuider-/Kleine Sluis, waarvan er dus 108 succesvol van de Zuider- en Kleine Sluis tezamen gebruikmaken, en waarvan 27 van de Kleine Sluis gebruikmaken. Het totale aanbod bij de Kleine Sluis wordt dan vastgesteld op 25\% (1/4 deel) van 555 = 139 schieralen. Van de 139 schieralen, die zich op grond van aannames hebben aangediend, hebben er minimaal 6 (4,3\%, of afgerond 4\%) gebruik gemaakt van de vismigratievoorziening en maximaal alle 26 (werkelijk) gedetecteerde alen (wat overeenkomt met 18,7\%, of afgerond 19\%). De 6 schieralen (nr. 1, 12, 18, 20, 23, 24) zijn in achtereenvolgende detecties, van binnen naar buiten, waargenomen bij de sluis. In het maximale geval (19\%) is ervan uitgegaan dat alle gedetecteerde schieralen ook daadwerkelijk de vismigratievoorziening zijn gepasseerd. De alen kunnen echter ook slechts één rinket zijn gepasseerd, of enkel in de buurt van de detectielus hebben begeven, zonder passage. De overige alen zijn de Kleine Sluis ongezien (schutting) gepasseerd of hebben een andere route gekozen.

De reden voor de lage passage-efficiëntie kan zeker worden gezocht in de hoge kanaalwaartse stroomsnelheden die zijn opgetreden via de rinketten tijdens momenten waarop de schieraal geacht werd de kolk binnen te zwemmen (HW1), en te verlaten (HW2). Deze zullen veelal te hoog zijn geweest voor passage, vermoedelijk veroorzaakt door de lekkages onder de kolkdeuren aan beide zijden van de kolk. Het grote aantal eenmalige detecties aan het binnenhoofd tijdens HW1, zonder vervolg aan het buitenhoofd en het aantal herhaalde detecties tijdens HW1 aan het binnenhoofd zullen dan ook deels vergeefse pogingen zijn geweest om de rinket te passeren. Wat ook nadelig was is dat de periode met een zeewaarts debiet tijdens LW in de donkere uren slechts $6 \%$ besloeg van de tijd waarbij de vismigratievoorziening actief was (Tabel 2a en Tabel 7).

Migratie patronen van buiten naar binnen

Dat er schieralen van buiten naar binnen trekken is opvallend. Echter, bij de schieralen die met een akoestische transmitter (VEMCO) zijn uitgerust zien we ook schieralen weer terugzwemmen het kanaal op via het spui/gemaal of de Noordersluis ( 2 op de 47 stuks $=4 \%$, Winter et al. 2019). Daarnaast zien we ook schieralen na passage door meerdere stations worden gedetecteerd waardoor de verblijftijd aan de buitenzijde voor een deel van de schieralen van langere duur kan zijn. Het zou goed kunnen dat ook bij de Kleine Sluis gemerkte schieralen hebben 'rondgehangen' en dus zijn gedetecteerd door de buitendeuren. Een deel zou dan ook van buiten naar binnen zijn getrokken waarvan nr. 2 en 22 met de stroming mee naar binnen en nr. 15 tijdens een schutting.

\section{Wat is de passage-efficiëntie van de vismigratievoorziening in de Kleine Sluis te IJmuiden voor uittrekkende schieraal.}

De resultaten in deze studie laten zien dat het gebruik van de vismigratievoorziening door uittrekkende schieralen beperkt is. Het overgrote deel van de schieralen trekt via de Noordersluis, het spui/gemaal of de Middensluis naar zee (ruim 94\%, Winter et al. 2019). Van de schieralen die bij de Kleine Sluis aankomen maakt tussen $4 \%$ en $19 \%$ geheel of gedeeltelijk (combinatie van passage via vismigratievoorziening en tijdens schutting) gebruik van de vismigratievoorziening om de Kleine Sluis te passeren. In het maximale geval $(19 \%)$ is ervan uitgegaan dat alle gedetecteerde schieralen ook daadwerkelijk de vismigratievoorziening zijn gepasseerd.

Mogelijk is er sprake van enige aantrekkende werking richting Kleine Sluis ten gevolge van de forse instroom van zeewater via de vismigratievoorziening, wat de uittrekverhouding tussen Kleine Sluis en Zuidersluis positief kan hebben beïnvloed en zelfs ten opzichte van de Middensluis een extra aantrekkende werking kan hebben gehad.

De vismigratievoorziening werkte niet optimaal door lekkages onder de deuren aan beide zijden van de kolk, waardoor te grote stromingen optraden door de rinketten. Bovendien zorgt de grote instroom van zeewater voor een extra verzilting van het Noordzeekanaal, die in perioden van droogte 
ongewenst is. Het is niet te voorspellen of bij een goede werking van de voorziening, waarbij de rinketten bij lagere stroomsnelheden goed passeerbaar zijn, een groter deel van het aanbod via de Kleine Sluis haar weg naar de Buitenhaven zal weten te vinden. 


\section{$5 \quad$ Aanbevelingen en dankwoord}

Uit deze studie blijkt dat de toegevoegde waarde van de vismigratie voorziening op de totale uittrekkende schieraal beperkt is.

Op basis van gegevens van Rijkswaterstaat blijkt dat de vismigratievoorziening gedurende het onderzoek niet optimaal werkte door lekkages onder de deuren aan beide zijden van de kolk, waardoor te grote stromingen optraden door de rinketten. Bovendien zorgt de grote instroom van zeewater voor een extra verzilting van het Noordzeekanaal, die in perioden van droogte ongewenst is. Het is niet te voorspellen of bij een goede werking van de voorziening, waarbij de rinketten bij lagere stroomsnelheden goed passeerbaar zijn, een groter deel van het aanbod aan schieraal via de Kleine Sluis haar weg naar de Buitenhaven zal weten te vinden.

Technische aanbevelingen t.a.v. vismigratie voorziening.

Tijdens de studie is gebleken dat de werking van de vismigratievoorziening kan worden verbeterd:

- Zorgen voor een goede afsluiting van de kolkdeuren, m.n. tegen de kolkvloer/drempel;

- Het niet aan weerszijden openzetten van de rinketten tijdens laagwater. Deze fase is slechts van korte duur en lastig beheersbaar. Het risico op het instromen van zeewater wordt hierdoor verminderd;

- Tijdens de eerste tweederde van de hoogwaterperiode, startend vanaf het begin ervan, aan de kanaalzijde twee rinketten geheel te openen en aan de zeezijde alles geheel te sluiten;

- Vervolgens de rinketten aan de kanaalzijde sluiten en aan de zeezijde twee tot vier rinketten geheel openen;

- Het activeren van de vismigratievoorziening enkel tussen zonsondergang en -opgang. Hierdoor wordt het schutproces en de vismigratiefunctie zoveel mogelijk gescheiden, wat oponthoud en storingen vermindert.

Voor een eventuele herhaling van de monitoring van de vismigratievoorziening zijn de aanbevelingen:

- Het uitvoeren van stromingsmetingen in de rinketten voor het verkrijgen van directe informatie over de stroomsnelheden, wat van belang is voor het inschatten van de passeerbaarheid van de rinketten voor vis;

- De monitoring zou kunnen worden herhaald, als zekerheid is verkregen dat de hydrauliek van de vismigratievoorziening op orde is, met een beperkte groep alen voorzien van PITtags die wordt uitgezet in het Zuiderbinnentoeleidingskanaal. Met de gebruikte techniek en huidige proefopzet kon worden vastgesteld dat schieralen zich nabij de rinketten van de deuren begeven. Echter, door het ontbreken van een dubbele lus bij elke rinket (binnen en buitenzijde van de deur), is het onmogelijk goed vast te stellen of een schieraal door de rinketten zwemt. Door technische randvoorwaarden (veiligheid en voorkomen schade aan de detectie lussen) was het met de huidige proefopzet niet mogelijk om in een operationele sluis een dubbele lus aan te brengen. In een mogelijke vervolg zou deze optie moeten worden verkend om zeker te zijn van een passage.

\section{Dankwoord}

Wij willen Marco van Wieringen (RWS) bedanken voor zijn bijdrage in deze rapportage in de vorm van feedback en gegevens analyse vanuit RWS. Verder willen wij Hendry Vis van VisAdvies bedanken voor zijn expertise bij het verhelpen / advies geven rondom storing bij de PIT-tag lussen in deze zeer uitdagende omgeving voor de gebruikte techniek! Als laatste Wals Diving voor hun medewerking in het veld en de plaatsing van de detectielussen op de deuren. 


\section{Bijlage: Regeling vismigratievoorziening 1e halfjaar (m.n. visintrek of 'voorjaar')}

Deze regeling wordt ingezet vanaf 1 februari tot aan 1 augustus. Voor dit onderzoek is deze regeling niet zo relevant, aangezien er in deze periode geen gemerkte schieralen zijn gedetecteerd in de Kleine Sluis. De vismigratievoorziening kent 3 fasen. Deze fasen zijn opeenvolgend en afhankelijk van het waterpeil aan de zeezijde (buitenwater). De normale werking in het eerste half jaar is als volgt ${ }^{4}$ : De laagwaterfase (LW) komt overeen met die tijdens het tweede halfjaar en dient voor het creëren van een zoetwaterbel voor de sluis aan de zeezijde om intrekkende vis te lokken naar de Kleine Sluis. De stroming zal te sterk zijn om tijdens fase LW de sluis binnen te zwemmen vanuit zee. Tijdens hoogwaterfase HW1 staan de schuiven aan de zeezijde allemaal volledig open. De kolk vult zich met zeewater en trekvis als glasaal en driedoornige stekelbaars kan de kolk (passief en actief) binnenzwemmen. Aan de kanaalzijde zijn de rinketten gesloten, met uitzondering van de meest zuidelijke die op een kier van $6 \%$ openstand staat. Hierdoor komt iets zoeter water de kolk in, met de bedoedeling de vis oriëntatie richting te geven bij het zich verplaatsen in de kolk. Iets voorbij het bereiken van het hoogste zeepeil start hoogwaterfase HW2, waarbij de schuiven aan de zeezijde worden dichtgezet en aan de kanaalzijde allemaal geheel geopend. In deze fase kunnen de vissen de kolk uitzwemmen met de uitstroom richting kanaal. Tijdens de monitoring van deze intrekregeling in 2018 is deze iets aangepast: tijdens de hoogwaterfase HW2 is daarbij slechts de meest zuidelijke rinketschuif volledig geopend en de overige schuiven dicht. Hierdoor was het mogelijk om met een fuik achter de geopende rinket de intrek van vis te monitoren (Manshanden 2018).

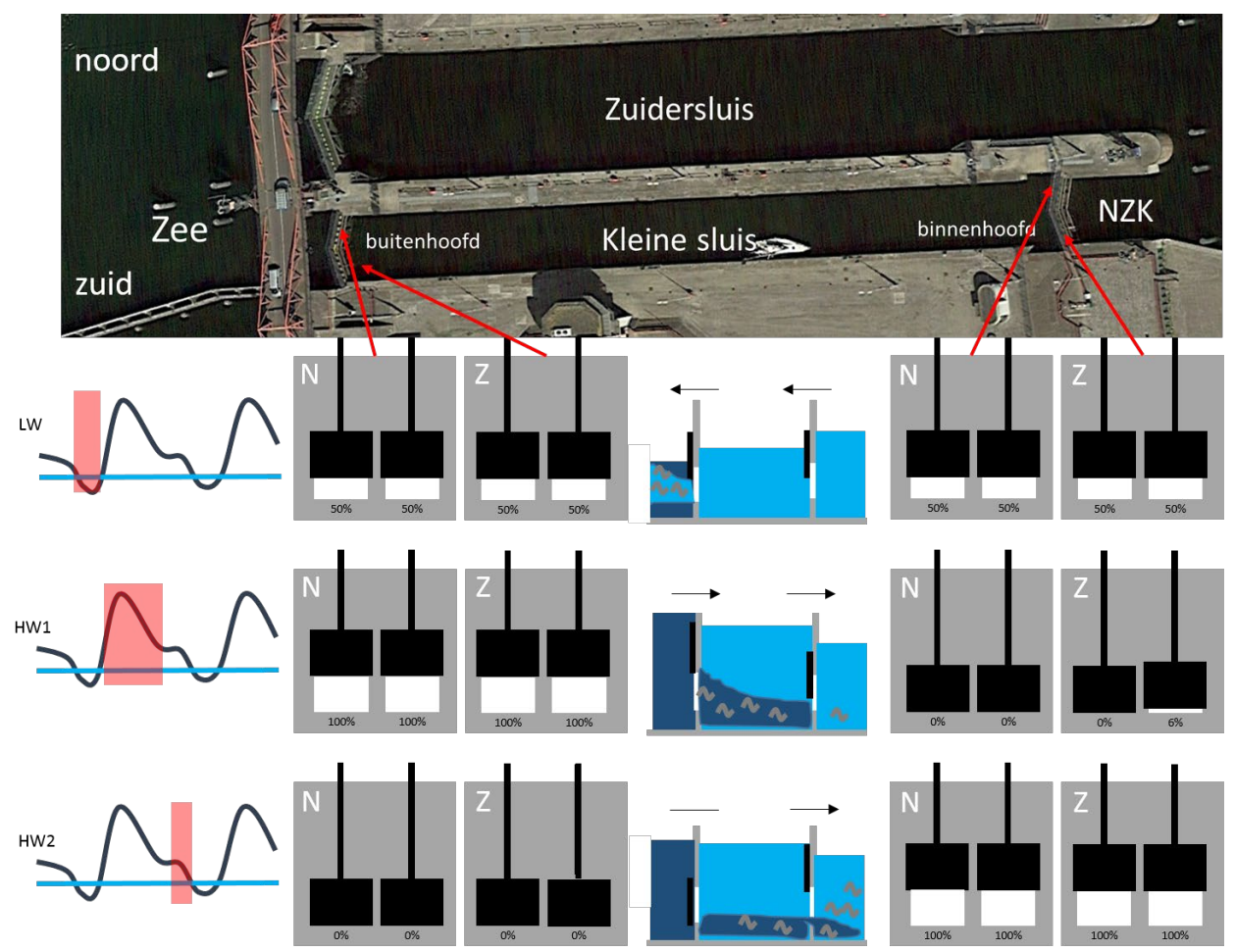

Figuur 2-1 schematische weergave van de regeling van de vismigratievoorziening Kleine Sluis in het $1^{\mathrm{e}}$ halfjaar, gericht op de intrek van glasaal en driedoornige stekelbaars. $L W=$ laagwater HW1 = Hoogwater fase 1, HW2 = Hoogwater fase 2.

\footnotetext{
${ }^{4}$ Regeling ingesteld per 5 juli 2017 (med. RWS)
} 


\section{$6 \quad$ Kwaliteitsborging}

Wageningen Marine Research beschikt over een ISO 9001:2015 gecertificeerd kwaliteitsmanagementsysteem. Dit certificaat is geldig tot 15 december 2021. De organisatie is gecertificeerd sinds 27 februari 2001. De certificering is uitgevoerd door DNV GL.

Het chemisch laboratorium te IJmuiden beschikt over een NEN-EN-ISO/IEC 17025:2005 accreditatie voor testlaboratoria met nummer L097. Deze accreditatie is geldig tot 1 april 2021 en is voor het eerst verleend op 27 maart 1997; deze accreditatie is verleend door de Raad voor Accreditatie. Het chemisch laboratorium heeft hierdoor aangetoond in staat te zijn op technisch bekwame wijze valide resultaten te leveren en te werken volgens de IS017025 norm. De scope (L097) met de geaccrediteerde analysemethoden is te vinden op de website van de Raad voor Accreditatie (www.rva.nl).

Op grond van deze accreditatie is het kwaliteitskenmerk $\mathrm{Q}$ toegekend aan de resultaten van die componenten die op de scope staan vermeld, mits aan alle kwaliteitseisen is voldaan. Het kwaliteitskenmerk $\mathrm{Q}$ staat vermeld in de tabellen met de onderzoeksresultaten. Indien het kwaliteitskenmerk $\mathrm{Q}$ niet staat vermeld is de reden hiervan vermeld.

De kwaliteit van de analysemethoden wordt op verschillende manieren gewaarborgd. De juistheid van de analysemethoden wordt regelmatig getoetst door deelname aan ringonderzoeken waaronder die georganiseerd door QUASIMEME. Indien geen ringonderzoek voorhanden is, wordt een tweede lijnscontrole uitgevoerd. Tevens wordt bij iedere meetserie een eerstelijnscontrole uitgevoerd. Naast de lijnscontroles wordende volgende algemene kwaliteitscontroles uitgevoerd:

- Blanco onderzoek.

- Terugvinding (recovery).

- Interne standaard voor borging opwerkmethode.

- Injectie standard.

- Gevoeligheid.

Bovenstaande controles staan beschreven in Wageningen Marine Research werkvoorschrift ISW 2.10.2.105.

Indien gewenst kunnen gegevens met betrekking tot de prestatiekenmerken van de analysemethoden bij het chemisch laboratorium worden opgevraagd.

Indien sprake is van onbeheerste kwaliteit worden passende maatregelen genomen. 


\section{Literatuur}

Arcadis, 2014. Verificatie simulaties alternatieven nieuwe zeesluis, onderzoek Chloride indringing Noordzeekanaal (ZTIJ). In opdracht van RWS WNN.

Clough, S.C., I.E. Lee-Elliott, A.W.H. Turnpenny, S.D.J. Holden en C. Hinks, 2004. Swimming Speeds in Fish: phase 2. R\&D Technical Report W2-049/TR1, Environment Agency Bristol.

Griffioen, A. B., O. A. van Keeken, and H. V. Winter, 2017. Pilot studie akoestische telemetrie nabij sluiscomplex IJmuiden. Wageningen Marine Research, IJmuiden.

Griffioen, A. B., and H. V. Winter, 2017. Schieraal uittrek Noordzeekanaal 2016 - een merk-terugvangst experiment met fuikvangsten. Wageningen University \& Research Rapport C050/17.

Jongeling, T., 2012. Vismigratie Kleine Sluis IJmuiden, Randvoorwaarden recreatievaart en bodembescherming. Memo RWS, Dienst Infrastructuur.

Klein Breteler, J.G.P., 2005. Kennisdocument Europese aal of paling, Anguilla anguilla (Linnaeus, 1758). Kennisdocument 11 OVB/Sportvisserij Nederland.

Manshanden, G.A.M., 2018. Monitoring visintrek Kleine sluis IJmuiden 2018. FishFlow Innovations i.o.v. RWS WNN. Rapport FF-1711.04.

Vis, H. \& I.L.Y. Spierts, 2010. Telemetrie-onderzoek migratie schieraal Noordzeekanaal 2009/2020. VisAdvies i.o.v. RWS NH. Rapport VA2009-52.

Winter, H. V., 2011. Effecten van Gemaal IJmuiden op de uittrek van schieraal: integratie van de onderzoeken tijdens de periode 2007 - 2011. IMARES, IJmuiden.

Winter, H.V., O.A. van Keeken, J. Brockötter, A.B. Griffioen , 2019. Migratiepatronen en -knelpunten uittrek schieraal Noordzeekanaal en ommelanden, inclusief Markermeer. Onderzoek met akoestische telemetrie en PIT-tags 2017-2018: eindrapport - CONCEPT. Wageningen Marine Research, IJmuiden. 


\section{Verantwoording}

Rapport C014/19

Projectnummer: 4316100115

Dit rapport is met grote zorgvuldigheid tot stand gekomen. De wetenschappelijke kwaliteit is intern getoetst door een collega-onderzoeker en het verantwoordelijk lid van het managementteam van Wageningen Marine Research

Akkoord

Edward Schram

Onderzoeker

Handtekening:

Datum:

14 februari 2019

Akkoord:

Jakob Asjes

Manager integratie

Handtekening:

Datum:

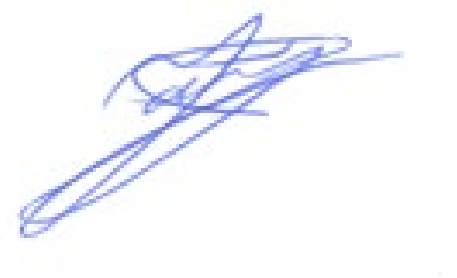

14 februari 2019 
Wageningen Marine Research

T: $+31(0) 317480900$

E: marine-research@wur.nl

www.wur.nl/marine-research

Visitors address

- Ankerpark 271781 AG Den Helder

- Korringaweg 7, 4401 NT Yerseke

- Haringkade 1, 1976 CP IJmuiden
Wageningen Marine Research is the Netherlands research institute established to provide the scientific support that is essential for developing policies and innovation in respect of the marine environment, fishery activities, aquaculture and the maritime sector.

Wageningen University \& Research is specialised in the domain of healthy food and living environment.

\section{The Wageningen Marine Research vision:}

'To explore the potential of marine nature to improve the quality of life.'

\section{The Wageningen Marine Research mission}

- To conduct research with the aim of acquiring knowledge and offering advice on the sustainable management and use of marine and coastal areas.

- Wageningen Marine Research is an independent, leading scientific research institute.

Wageningen Marine Research is part of the international knowledge organisation Wageningen UR (University \& Research centre). Within Wageningen UR, nine specialised research institutes of Stichting Wageningen Research (a Foundation) have joined forces with Wageningen University to help answer the most important questions in the domain of healthy food and living environment. 